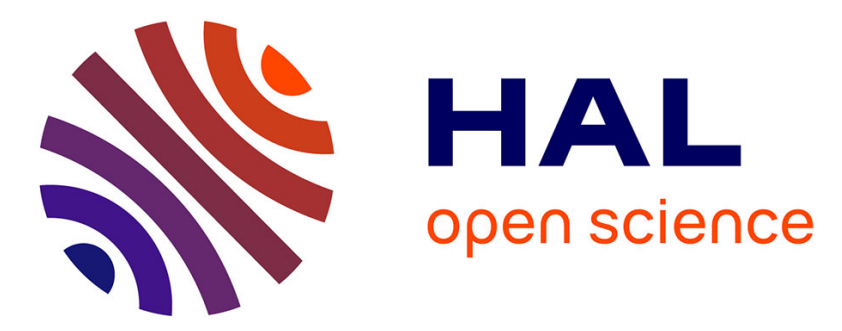

\title{
Remanence of lead pollution in an urban river system : a multi-scale temporal and spatial study in the Seine River basin, France
}

Sophie Ayrault, P. Le Pape, O. Evrard, C.R. Priadi, Cécile Quantin, P. Bonté, M. Roy-Barman

\section{To cite this version:}

Sophie Ayrault, P. Le Pape, O. Evrard, C.R. Priadi, Cécile Quantin, et al.. Remanence of lead pollution in an urban river system: a multi-scale temporal and spatial study in the Seine River basin, France. Environmental Science and Pollution Research, 2014, 21 ((6):), pp.4134-4148-6 (IF 2,618). 10.1007/s11356-013-2240-6 . hal-00913151

\section{HAL Id: hal-00913151 https://hal.science/hal-00913151}

Submitted on 15 May 2020

HAL is a multi-disciplinary open access archive for the deposit and dissemination of scientific research documents, whether they are published or not. The documents may come from teaching and research institutions in France or abroad, or from public or private research centers.
L'archive ouverte pluridisciplinaire HAL, est destinée au dépôt et à la diffusion de documents scientifiques de niveau recherche, publiés ou non, émanant des établissements d'enseignement et de recherche français ou étrangers, des laboratoires publics ou privés. 
Total lead $(\mathrm{Pb})$ concentration and $\mathrm{Pb}$ isotopic ratio $\left({ }^{206} \mathrm{~Pb} /{ }^{20} 7 \mathrm{~Pb}\right)$ were determined in 140

samples from the Seine River basin (France), covering a period time from 1945 to 2011 and

20 including bed sediments (bulk and size fractionated samples), suspended particulate matter

21 (SPM), sediment cores, and combined sewer overflow (CSO) particulate matter to constrain the

spatial and temporal variability of the lead sources at the scale of the contaminated Seine River basin. A focus on the Orge River sub-catchment, which exhibits a contrasted land-use pattern, allows documenting the relation between hydrodynamics, urbanization and contamination sources. The study reveals that the $\mathrm{Pb}$ contamination due to leaded gasoline that peaked in the 1980s has a very limited impact in the river nowadays. In the upstream Seine River, the isotopic ratio analysis suggests a pervasive contamination which origin (coal combustion and/or gasoline lead) should be clarified. The current SPM contamination trend follows the urbanization/industrialization spatial trend. Downstream of Paris, the lead from historical use originating from the Rio Tinto mine, Spain $\left({ }^{206} \mathrm{~Pb} /{ }^{207} \mathrm{~Pb}=1.1634 \pm 0.0001\right)$ is the major $\mathrm{Pb}$ source. The analysis of the bed sediments (BS) (bulk and grain size fractionated) highlights the diversity of the anthropogenic lead sources in relation with the diversity of the human activities that occurred in this basin over the years. The "urban" source, defined by waste waters

34 including the CSO samples $\left({ }^{206} \mathrm{~Pb} /{ }^{207} \mathrm{~Pb}=1.157 \pm 0.003\right)$, results of a thorough mixing of leaded gasoline with "historical" lead over the years. Finally, a contamination mixing scheme related to hydrodynamics is proposed.

Keywords: suspended particulate matter, lead isotopes, sewer overflow, urban lead, sediment cores 


\section{Introduction}

Lead $(\mathrm{Pb})$ is a problematic metallic contaminant in numerous river systems across the world (Kachur et al., 2003; Sun et al., 2011; Grosbois et al., 2012). Reconstructing the history of $\mathrm{Pb}$ contamination and quantifying the dynamics of $\mathrm{Pb}$ transport in river systems is important to design appropriate remediation policies and evaluate their environmental impact. The historical record of $\mathrm{Pb}$ contamination in river sediments may be accessed by dating and analyzing sediment cores collected within floodplains (Alfonso et al., 2001; Ayrault et al, 2012). In addition, the comparison of lead concentrations and lead isotopic ratios along the entire sediment sequence may provide powerful constrains on the evolution of natural and anthropogenic sources that supplied $\mathrm{Pb}$ to the river throughout time (Monna et al., 2000; Shotyk et al., 1998). However, extrapolation of floodplain data to the whole river system is not straightforward because of several problems detailed hereafter. Fine particles that deposit in floodplains may differ in $\mathrm{Pb}$ concentration and isotopic composition from coarse bed sediment particles that may represent a large fraction of the river particulate flux (Horowitz and Elrick, 1987; Stone and Droppo, 1996). Moreover, fine particles collected in floodplains during a short time period (i.e., during high water stages) may not be representative of the average fine particles transported by the river.

Therefore, the relevance and/or the impact of those potential biases must be evaluated to strengthen the understanding of $\mathrm{Pb}$ behavior in river systems. In the present study, we focus on the Seine River system $\left(64,700 \mathrm{~km}^{2}\right)$ which is highly impacted by $\mathrm{Pb}$ contamination (Meybeck et al., 2007, Ayrault et al., 2012). The Seine catchment is affected by very high anthropogenic pressures and is characterized by a very limited dilution of metallic contaminants due to the low suspended matter concentrations prevailing in the Seine River waters. As a consequence, the Seine Basin is structurally fragile and its river course, downstream of Paris megacity, has been and is still ranked among the world's most contaminated rivers (Meybeck et al., 2007). Indeed, cores collected within a floodplain located downstream of Paris revealed high levels of contamination ( $\mathrm{Pb}$ up to $400 \mathrm{mg} / \mathrm{kg}$ ) between 1920s and 1960s followed by a decrease in $\mathrm{Pb}$ 
concentrations since 1960. In 2003, $\mathrm{Pb}$ concentrations $(\mathrm{Pb} \approx 50 \mathrm{mg} / \mathrm{kg})$ were still significantly above the estimated geochemical background ( $\mathrm{Pb} \approx 20 \mathrm{mg} / \mathrm{kg}$, Thévenot et al., 2007). The contribution of three main sources that may be used as « end-members » in mixing models (Ayrault et al., 2012) has been previously identified based on the use of stable Pb isotopes ( a full literature review can be found in Komarek et al., 2008). (1) The local natural background signature $\left({ }^{206} \mathrm{~Pb} /{ }^{207} \mathrm{~Pb}=1.2007 \pm 0.0011\right)$ was determined using a $8000 \mathrm{BP}-{ }^{14} \mathrm{C}$ dated sediment (Elbaz-Poulichet et al., 1986). A very similar value $\left({ }^{206} \mathrm{~Pb} /{ }^{207} \mathrm{~Pb}=1.2035\right.$ ) was obtained in an undisturbed $\mathrm{C}$ soil horizon developed in loess deposits collected next to the Chateau de Versailles gardens (Semlali et al., 2004). Those soils are widely found in the Seine River watershed, particularly in its downstream part. (2) The lead from historical (hereafter called "historical" $\mathrm{Pb}$ ) originating from the Rio Tinto mine in $\mathrm{Spain}\left({ }^{206} \mathrm{~Pb} /{ }^{207} \mathrm{~Pb} \approx 1.1634 \pm 0.0001\right.$; Marcoux, 1998) that has accumulated in the Seine basin since the $19^{\text {th }}$ century at least (Ayrault et al., 2012). (3) $\mathrm{Pb}$ used in additives to gasoline $\left({ }^{206} \mathrm{~Pb} /{ }^{207} \mathrm{~Pb}=1.08 \pm 0.02\right)$, that contain high proportions of Australian lead from the Broken Hill mine $\left({ }^{206} \mathrm{~Pb} /{ }^{207} \mathrm{~Pb} \approx 1.040 \pm 0.001\right)$; this latter signature was determined based on information from Octel Ltd at Paimboeuf, which was the single provider of leaded additives for French gasoline (Véron et al., 1999). A fourth source of lead to Parisian soils, coal combustion, has been evidenced by Semlali et al. (2004) $\left({ }^{206} \mathrm{~Pb}{ }^{207} \mathrm{~Pb} \sim 1.183\right)$ but was not detected by Ayrault et al. (2012) in the downstream core sediments.

Over the years, mixing between "historical" and "gasoline" Pb have yielded a composite "urban" $\mathrm{Pb}$ signature $\left({ }^{206} \mathrm{~Pb} /{ }^{207} \mathrm{~Pb}=1.154 \pm 0.002\right)$, as determined by analyzing waste water treatment plant (WWTP) effluents collected in 2006 (Ayrault et al., 2012). Owing to this mixing, the "urban" end-member is supposed to vary in both space and time, in particular because of the prohibition of gasoline leaded additives in 2000. However, despite their sampling during different campaigns and the different nature of the analyzed urban wastes (liquid/solid), the WWTP signature did not significantly differ from the signature of the three major Parisian municipal solid waste incinerators in 2001 (1.1550 \pm 0.0005 ; Widory, 2004). It appeared therefore necessary to constrain the evolution of the "urban" Pb signature at different scales 
within the Seine River basin.

Previous work showed a significant decrease in the gasoline-originated lead contribution to the Seine River sediment contamination from 1986 to 2003 due to the implementation of regulations on the use of leaded gasoline additives and their subsequent ban in 2000 (Ayrault et al., 2012). In this context, $\mathrm{Pb}$ found in the Seine River is dominated by a mixing between urban lead (coinciding with high lead concentration) and natural lead (coinciding with low lead concentration). Similar trends were observed in the very urbanized Orge River subcatchment $\left(1300 \mathrm{~km}^{2}\right)$ (Le Pape et al., 2013).

Atmospheric $\mathrm{Pb}$ deposition across the Seine River basin was estimated to vary between 2000 (1994-2003; Thévenot et al., 2007) and 2900 t.y ${ }^{-1}$ (1955-2004; Saby et al., 2006), whereas the $\mathrm{Pb}$ emissions were estimated to 2700 t.y $^{-1}$ (1955 to 2004, considering that the Seine River basin contributes to $30 \%$ of the total French emissions; Pacyna and Pacyna, 2000). In addition to the $\mathrm{Pb}$ accumulation in soils, a large urban stock of $\mathrm{Pb}$ exists in the region. Thévenot et al. (2007) constructed the $\mathrm{Pb}$ budget at the scale of the Seine River basin. They concluded that a huge amount (594,000 t) of $\mathrm{Pb}$ has accumulated since centuries in Paris megacity because of its use in roof covers, pipes, cables shielding, oxide containing glasses, etc. These stocks show different environmental behaviors and lifetimes.

Pb-bearing soil particles may be delivered to the rivers during erosion events. The Seine River basin is affected by low to moderate soil erosion rates, which is reflected by mean exports estimated to $10 \mathrm{t} \cdot \mathrm{km}^{-2} \cdot \mathrm{y}^{-1}$ (Meybeck et al., 1998). The residence times of particles in soils are long (5000-40,000 yrs depending on their location within the catchment). In contrast, the residence time of the particles within the river is much shorter (180-500 days) Altogether, those findings led us to investigate whether gasoline-originated lead could have been completely washed out from the Seine River basin since their ban in 2000. The complete flush of the gasoline-lead bearing particles would then provide an original and alternative method to evaluate the sediment turnover of the river.

We propose to compile $\mathrm{Pb}$ elemental and isotopic data collected on different material types (i.e. suspended particulate matter, riverbed sediment, overflow plain sediment) along a network of 
nested stations to document the processes occurring at different temporal scales (flood, seasonal, annual, decadal) and at two catchment scales: Seine $\left(64,700 \mathrm{~km}^{2}\right)$ vs. Orge $\left(1300 \mathrm{~km}^{2}\right)$. However, owing to evident logistical and analytical constrains, it was not possible to conduct such a detailed study compiling $\mathrm{Pb}$ data measured in all sediment types (suspended particulate matter (SPM), bed sediment (BS)) and taking into account the different hydrological stages throughout the year at the scale of the entire Seine River basin. We therefore focused a significant part of the sampling effort on the Orge River basin $\left(1300 \mathrm{~km}^{2}\right)$, which drains into the Seine River just upstream of Paris, because its land uses are characterized by a gradient of increasing anthropogenic influence along its course, from headwaters dominated by forests and cropland to its junction with the Seine River where its flows across densely inhabited areas (Le Pape et al., 2012). Detailed investigation of the processes occurring in this catchment will provide important insights on the role of river hydrodynamics and provide a way to better constrain the relative contribution of pollution sources in space and time (Le Pape et al., 2013). We will finally attempt to extrapolate the conclusions drawn from the Orge River study to the entire Seine River basin.

\section{Materials and Methods}

\subsection{Study sites}

All sampling sites were located in the Seine River basin (Fig. 1), a sedimentary basin situated in the north of France, and flowing across the Greater Paris Region. This river drains an area of $64,700 \mathrm{~km}^{2}$ characterized by a mean population density of $215 \mathrm{inh} . / \mathrm{km}^{2}$, and constitutes therefore an ideal example of highly urbanized basin as it accounts for $25 \%$ of French agriculture, $30 \%$ of the country's industry and $23 \%$ of its population. The Orge River subcatchment is located in the upper part of the Seine River basin, and drains an area of 1300 $\mathrm{km}^{2}$ with a population density ranging between $200 \mathrm{inh} . / \mathrm{km}^{2}$ in upper parts to $8000 \mathrm{inh} . / \mathrm{km}^{2}$ close to the junction with the Seine River.

\section{Figure 1}

\subsection{Sampling}

All the sample locations and collection periods are detailed in Table 1.

Table 1 


\subsubsection{Suspended sediment from the entire Seine River basin}

At the scale of the whole Seine River basin, the sampling scheme aimed to distinguish the impacts of two anthropogenic sources on the Seine River (Priadi et al., 2011a). The first source is diffuse and coincides with the area of Greater Paris itself, including the most densely urbanized area with more than $3700 \mathrm{inh} . / \mathrm{km}^{2}$. Treated municipal wastewater from small treatment units and urban runoff are the major sources identified as supplying metal to the river in this area (Thévenot et al., 2007). The second source is point-based, and coincides with the Seine-Aval wastewater treatment plant (WWTP) treating around 1.7 million $\mathrm{m}^{3}$ per day and located $30 \mathrm{~km}$ downstream of Paris. Therefore, the first sampling site was located at Marnay-sur-Seine, in upper parts of the Seine River catchment (Priadi et al. 2011b, and Fig.1). It was chosen as being representative of a site unaffected by the Greater Paris region where the population density is only $15-30$ inhabitants $/ \mathrm{km}^{2}$. The second site is located at Bougival, $40 \mathrm{~km}$ downstream of Paris city (Strahler order 7). It was chosen to study the impact of Greater Paris just upstream of the Seine-Aval WWTP effluent outflow. A third site, located $40 \mathrm{~km}$ further downstream, at Triel-sur-Seine, was selected to take the additional inputs of this WWTP into account. The Triel station is situated downstream of the junction between the Seine River and one of its major tributaries, the Oise River. SPM sampling was performed in sediment traps collected monthly from October 2008 to October 2009.

\subsubsection{Riverbed sediment (BS) from the entire Seine River basin}

Riverbed sediments were collected in the framework of the National River Network (sampling operated by the Service Navigation de la Seine (SNS)) in 2007-2009, at a succession of sites within Paris as well as along the 10-km river section located just downstream of Paris.

\subsubsection{Combined sewer overflow (CSO) sampling.}


185 Details on the CSO sampling are given in Passerat et al. (2011). The CSO occurred in August 2008, during a summer storm that affected Paris. It lasted for 6 h (from 5:50 a.m. to 11:50 a.m.) and resulted in the discharge of ca. $600,000 \mathrm{~m}^{3}$ of untreated urban waste water into the Seine River. Twelve successive samples were collected automatically in the CSO, each sample being a time-proportional composite of the waters discharged during a 30-min period. The analyses of each sample allowed to apportion the volume of domestic waste water and the runoff over the CSO duration. In parallel, the plume impacted by the CSO was sampled four times during its flow from the release point to a distance of $20 \mathrm{~km}$.

\subsubsection{Sediment sampling in the Orge subcatchment}

Sampling campaigns were performed in 2001 and in 2010/2011 along the Orge River, including two of its tributaries, to exhibit spatio-temporal trends of urban contamination at the scale of this small but densely populated catchment (Le Pape et al., 2012). Sampling sites were selected to document the urbanization and land use gradients: upstream sites in forests and agricultural areas "D" (for Dourdan) and "C" (for Saint Chéron), the sites "R" (for Rémarde) and "E" (for Egly) considered to be under a slight urban influence, and the most urbanized downstream sites "L" (for Longpont-sur-Orge), "Y" (for Yvette) and "V" (for Viry-Chatillon). The bed sediments sampled in the Orge River (10 uppermost $\mathrm{cm}$ ) during the 2010/2011 campaigns were frozen and quickly freeze-dried. For the third campaign (April 2011), 10 to 15 $\mathrm{g}$ of each bed sediment sample were sieved using deionized water and separated into three grain size fractions: $>200 \mu \mathrm{m}, 200 \mu \mathrm{m}>\mathrm{X}>63 \mu \mathrm{m}$, and $<63 \mu \mathrm{m}$. Each recovered fraction composed of water and sediment was then dried at $40^{\circ} \mathrm{C}$ in an oven. After drying, the mass of each fraction was measured and compared to the initial mass of sediment sieved to calculate the contribution (\% mass) of each grain size in the samples.

Chemical and lead isotopes analyses were finally carried out on one crushed gram of each grain size fraction, following the methods described in sections 2.3 and 2.4.

\subsection{Elemental determination}

The Seine River and Orge River SPM and BS samples were totally digested according to the procedures described in Priadi et al. (2011b) and Le Pape et al. (2012). In brief, the total digestion step was conducted in PTFE closed flasks, on a digestion block (Digiprep, SCP Science) by successive additions of concentrated ultra-pure acids $\left(\mathrm{HCl}, \mathrm{HNO}_{3}, \mathrm{HF}\right.$, and $\left.\mathrm{HClO}_{4}\right)$. 
217 The solutions were evaporated to dryness, retaken 3 times in $2 \mathrm{~mL}$ of $\mathrm{HNO}_{3}$ and then diluted

218 with $50 \mathrm{~mL}$ of MilliQ water. The elemental content was analyzed by inductively coupled plasma

219 - mass spectrometry ICP-MS (XII CCT series, Thermo Electron), according to the procedures

220 referred to above. The Seine River cores samples analyses were described in Ayrault et al.

221 (2012). The data quality of the elemental concentration determination was controlled with the reference material IAEA-SL-1 (lake sediment), provided by the International Atomic Energy Agency, Vienna. The values obtained with this procedure were in good agreement with the certified values. The uncertainties of the determination of $\mathrm{Pb}$ and $\mathrm{Al}$ concentrations discussed in the present paper were $5 \%$ and $14 \%$, respectively.

\subsection{Lead isotopes ratio determination.}

Lead isotope ratios $\left({ }^{208} \mathrm{~Pb} /{ }^{206} \mathrm{~Pb}\right.$ and $\left.{ }^{206} \mathrm{~Pb} /{ }^{207} \mathrm{~Pb}\right)$ were measured in the same solutions as for elemental concentration determinations, after appropriate dilution, using a ICP-QMS (X Series, ThermoElectron, France), following the procedure detailed in Ayrault et al. (2012). The experimental conditions were three channels reading; dwell time of $30 \mathrm{~ms} ; 100$ sweeps; 5 replicates per sample. Mass bias and drift of the isotope ratios were corrected based on repeated measurements of the $\mathrm{Pb}$ reference material NIST SRM-981 that was analyzed every three samples. SRM-981 was also repeatedly analyzed as a sample to control the bracketing correction. Certified values for the SRM- 981 are ${ }^{206} \mathrm{~Pb} /{ }^{207} \mathrm{~Pb}=1.09333 \pm 0.00039$. The figure of merits for the Seine River core samples and the Orge River SPM are in Ayrault et al. (2012) and Le Pape et al. (2013), respectively. For the Orge River bulk and sieved BS analyses, the ratio was ${ }^{206} \mathrm{~Pb} /{ }^{207} \mathrm{~Pb}=1.0933 \pm 0.0025(\mathrm{n}=14)$. For the Seine River BS and trapped SPM analyses, the measured ratio were ${ }^{206} \mathrm{~Pb} /{ }^{207} \mathrm{~Pb}=1.0933 \pm 0.0018(\mathrm{n}=4)$ and ${ }^{206} \mathrm{~Pb} /{ }^{207} \mathrm{~Pb}=1.0929 \pm 0.0027$ $(\mathrm{n}=19)$, respectively.

\subsection{Enrichment factor}

The lead concentrations in the SPM are expressed as an enrichment factor (EF) calculated in reference to the local geochemical background and normalized by the SPM aluminum (Al) contents with the following background concentrations: $\mathrm{Pb}=20 \mathrm{mg} / \mathrm{kg}$ (Meybeck et al., 2004; 
246 Thévenot et al., 2007) and background $\mathrm{Al}=36 \mathrm{~g} / \mathrm{kg}$ (Thévenot et al., 2007), (Eq. 1). The 20

$247 \mathrm{mg} / \mathrm{kg}$ value may be overestimated, due to the anthropogenic disturbance of the watershed and

248 the difficulty to sample pristine sediment. The systematic analysis of the various lithologies

249 found in the Seine River would be necessary to confirm the relevance of this value, as proposed

250 by Reimann and de Caritat (2005). Similar limitations could be drawn on Al background

251 concentration that may be underestimated in the upstream part of the catchment and particularly

252 in the crystalline Yonne River subcatchment, whereas it may be overestimated in the

253 downstream part of the catchment after the confluence with the Marne River draining

254 carbonate-rich substrates/rocks. The EF of the Bouafles sediment core were calculated using

255 scandium ( $\mathrm{Sc}$ ) instead of $\mathrm{Al}$, considering the background value of $\mathrm{Sc}=11 \mathrm{mg} / \mathrm{kg}$ (Ayrault et al., 256 2010).

257

$$
E F(P b)=\frac{\frac{[\text { measured } P b]}{[\text { measured } A l]}}{\frac{[\text { background } P b]}{[\text { background } A l]}} \quad(\text { Eq. 1) }
$$

258

259

260

\section{Results}

261

262

263

\subsection{Pb concentration}

In the Seine River, $\mathrm{Pb}$ concentration ranged from 75 to $282 \mathrm{mg} / \mathrm{kg}$ in the bed sediments (BS)

(Table 2) and from 18 to $245 \mathrm{mg} / \mathrm{kg}$ in the SPM (Table 3). These concentrations remained generally consistent with those measured in the TR01 upstream core $(40-90 \mathrm{mg} / \mathrm{kg}$; Ayrault et al., 2012). The downstream cores B2 and M1 exhibited much higher concentrations in the SPM deposited prior to 1970 (up to $460 \mathrm{mg} / \mathrm{kg}$ ). Overall, there is a $\mathrm{Pb}$ concentration gradient increasing from the upstream areas, i.e. with low urbanization/industrialisation and low $\mathrm{Pb}$ content, to the downstream areas, i.e. with high urbanization/industrialisation and high $\mathrm{Pb}$

\section{3 urbanized/industrialized area and to 4-22 in the "dirty water plume". It even peaked up to} concentration. Extremely high $\mathrm{Pb}$ concentrations are obtained in the CSO samples $(\mathrm{Pb}=244-948$ $\mathrm{mg} / \mathrm{kg}$ ) and in the CSO plume generated in the Seine River $(\mathrm{Pb}=175-407 \mathrm{mg} / \mathrm{kg}$ ) (Table 4). The EF ranged from 1 in the less urbanized/industrialized area (Marnay) to 3-11 in most 54-105 in the CSO samples. 
The $\mathrm{Pb}$ content in the Orge River BS ranged from 15 to $83 \mathrm{mg} / \mathrm{kg}$ in the bulk bed sediments and remained much lower than in the SPM collected at the same locations (Table 5). There was no increase in the $\mathrm{BS} \mathrm{Pb}$ concentration along the urbanization gradient. For SPM, the correlation is only valid during high water periods. In the case of the size fractionated bed sediments of the Orge River, the range of $\mathrm{Pb}$ concentration was somewhat larger $(10-110 \mathrm{mg} / \mathrm{kg})$, but remained in the same order of magnitude.

Table 5

286

\section{2. ${ }^{206} \mathrm{~Pb} /{ }^{207} \mathrm{~Pb}$ ratio}

The ${ }^{206} \mathrm{~Pb} /{ }^{207} \mathrm{~Pb}$ ratio measured in most of the Seine River (SPM and bed sediments) and Orge River basins (bed sediments) ranged from 1.15 to 1.18 . Only one sample of bed sediment collected in the Seine River had a ${ }^{206} \mathrm{~Pb} /{ }^{207} \mathrm{~Pb}$ ratio as low as $1.138 \pm 0.002$. In the Seine River, there is a rough correlation between the degree of urbanization/industrialization of the area sampled and the ${ }^{206} \mathrm{~Pb} /{ }^{207} \mathrm{~Pb}$ ratio measured in the SPM and the bed sediments. Hence, the study of Seine River SPM collected each month in sediment traps (2008-2009) showed an upstream-downstream trend with a signature decreasing from $1.175 \pm 0.003$ for the most upstream site to ${ }^{206} \mathrm{~Pb} /{ }^{207} \mathrm{~Pb}=1.1627 \pm 0.0025(\mathrm{n}=9$ site $\mathrm{T}$ ) in the most downstream section of the Seine River. The signature of this site sampled over one hydrological year fits well with the signature determined in the upper section of the cores, corresponding to sediment deposited in 2003. We can therefore conclude that the signature derived from the dated floodplain cores is representative of the average annual signature of the SPM.

\section{Figure 2.}

In contrast, the study of the Seine River bed sediment showed variable signatures (from ${ }^{206} \mathrm{~Pb} /{ }^{207} \mathrm{~Pb}=1.138 \pm 0.003$ to $1.165 \pm 0.002$ ) coupled to very variable lead contents. Among the 7 samples studied here, two sites have been sampled twice (yearly sampling during low waterflow), exhibiting significant variation between samples (e.g., at site $\mathrm{Sar},{ }^{206} \mathrm{~Pb} /{ }^{207} \mathrm{~Pb}=$ $1.163 \pm 0.002$ and $1.158 \pm 0.003$, in 2008 and 2009, respectively; Table 2). Above all, the bed sediment collected at Colombes in August 2009 combines the highest lead content being and the highest gasoline lead contribution to the isotopic ratio. After removing this point from further analysis, the bed sediments collected between 2007 and 2009 at locations close to the Bougival 
310 site had an average isotopic signature of ${ }^{206} \mathrm{~Pb} /{ }^{207} \mathrm{~Pb}=1.163 \pm 0.003(\mathrm{n}=6)$, close to the trapped $311 \mathrm{SPM}$ at site $\mathrm{B}\left({ }^{206} \mathrm{~Pb} /{ }^{207} \mathrm{~Pb}=1.161 \pm 0.002, \mathrm{n}=8\right)$. This indicates that both SPM and bed

312 sediment are associated with similar sources, but that bed sediment composition may be

313 punctually affected by local releases or river hydrodynamic changes. SPM and riverbed

314 sediment may be submitted to differential transport processes (Chon et al., 2012).

315 In the Orge River, the lead signature of the BS remained close to that of the SPM. Surprisingly,

316 BS collected during high waterflow exhibited a $\mathrm{Pb}$ signature close to the one of urban lead at all

\subsection{Temporal variability of lead sources in the Seine River}

\section{Discussion}

Figure 3

During most of the $20^{\text {th }}$ century, $\mathrm{Pb}$ found in the Seine sediments originated from the huge amount of this metal that has accumulated in Paris since the $19^{\text {th }}$ century (in painting, roof single elements, ...) and coming ultimately from the Rio Tinto mine. At the end of the $20^{\text {th }}$ century, the isotopic composition of the downstream sediment core showed that "gasoline" $\mathrm{Pb}$ supplied up to $20 \%$ of the $\mathrm{Pb}$ contained in the Seine River sediment, with a peak around 1986 (Ayrault et al., 2012). "Gasoline" $\mathrm{Pb}$ was over-represented in the Seine River sediments compared to other possible sources/stocks, most likely because it was emitted directly to the atmosphere and often deposited in urban areas where it was rapidly washed out towards the Seine River. Natural $\mathrm{Pb}$ in the Seine River basin has a distinct isotopic signature $\left({ }^{206} \mathrm{~Pb} /{ }^{207} \mathrm{~Pb}=1.2007\right)$. We can therefore use $\mathrm{Pb}$ isotopes to determine the nature and contribution of the different $\mathrm{Pb}$ sources to the environment.

Mixing between $\mathrm{Pb}$ of different sources can be studied with diagrams representing the isotopic 
342 ratio as a function of the inverse of the concentration, as a binary mixing produces a linear 343 correlation (Ayrault et al., 2012).

344 We considered a sediment (s) constituted of 3 components: a natural component (n), an 345 anthropogenic component (a) and a Pb-free component (d) that dilutes the two others. The 346 sample mass, $\mathrm{Pb}$ concentration, $\mathrm{Al}$ concentration and $\mathrm{Pb}$ isotopic ratio are noted $m, \mathrm{~Pb}, \mathrm{Al}$ and $R$, 347 respectively. Mixing equations are:

$348 \quad m_{s}=m_{n}+m_{a}+m_{d}$ (Eq. 2)

$349 A l_{s}=\frac{\left(m_{n} A l_{n}+m_{a} A l_{a}+m_{d} A l_{d}\right)}{m_{s}}($ Eq. 3)

$350 \quad P b_{s}=\frac{\left(m_{n} P b_{n}+m_{a} P b_{a}+m_{d} P b_{d}\right)}{\left(m_{s}\right)}($ Eq. 4)

$R_{s}=\frac{\left(m_{n} P b_{n} R_{n}+m_{a} P b_{a} R_{a}+m_{d} P b_{d} R_{d}\right)}{C_{S}}($ Eq. 5)

352 By definition, $P b_{\mathrm{d}}=0$. In addition, we assume that $A l_{\mathrm{d}}=0$ and $A l_{\mathrm{a}}=0$

$353 A l_{s}=\frac{m_{n} A l_{n}}{m_{s}}$ (Eq. 6)

$354 P b_{s}=\frac{\left(m_{n} P b_{n}+m_{a} P b_{a}\right)}{m_{s}}($ Eq. 7)

$R_{s}=\frac{\left(m_{n} P b_{n} R_{n}+m_{a} P b_{a} R_{a}\right)}{C_{s}}($ Eq. 8)

357 The EF calculation equation (Eq. 1) may then be written as:

$E F=\frac{\left(P b_{s} / A l_{s}\right)}{\left(P b_{n} / A l_{n}\right)}=\frac{\left(m_{n} P b_{n}+m_{a} P b_{a}\right) / m_{n} A l_{n}}{\left(P b_{n} / A l_{n}\right)}=1+\frac{m_{a} P b_{a}}{m_{n} P b_{n}}($ Eq. 9)

360 Dividing the numerator and denominator of Eq. 8 by $m_{n} P b_{n}$, we obtain:

$$
R_{S}=\frac{\left(R_{n}+\frac{m_{a} P b_{a}}{m_{n} P b_{n}} R_{a}\right)}{1+\frac{m_{a} P b_{a}}{m_{n} P b_{n}}}
$$

$$
=\frac{R_{n}+(E F-1) R_{a}}{E F}
$$

365 Therefore, the mixing of the two Pb-bearing phases "natural" + "anthropogenic" diluted by 
$366 \mathrm{~Pb}$-free materiel (e.g., quartz sand) produces a linear relationship between the ${ }^{206} \mathrm{~Pb} /{ }^{207} \mathrm{~Pb}$ ratio and 1/EF. Suspended particles collected in 2008/2009 at sites M, B and T form a broad linear array in $\mathrm{a}^{206} \mathrm{~Pb} /{ }^{207} \mathrm{~Pb}$ vs $1 / \mathrm{EF}$ diagram with the EF factor increasing (1/EF decreasing) from weakly to highly urbanized and industrialized area (Fig. 2). It suggests a mixing between an anthropogenic and a natural end-member.

The isotopic signature of the "natural" end member should be defined by the ${ }^{206} \mathrm{~Pb} /{ }^{207} \mathrm{~Pb}$ ratio at $\mathrm{EF}=1$. It corresponds to the Marnay sediments, in which ${ }^{206} \mathrm{~Pb} /{ }^{207} \mathrm{~Pb}$ ratio is significantly below the ${ }^{206} \mathrm{~Pb} /{ }^{207} \mathrm{~Pb}$ ratio $(=1.20)$ of the natural end-member determined in the literature. This difference might be due to locally different bedrocks or to pervasive contamination by gasoline $\mathrm{Pb}$ or both. Only $20 \%$ of gasoline lead would be sufficient to shift the ${ }^{206} \mathrm{~Pb} /{ }^{207} \mathrm{~Pb}$ ratio of the Marnay sediment from 1.20 to 1.18 . Such a small EF variation might not be significantly resolvable considering the uncertainties on the natural background $\mathrm{Pb}$ level discussed above. The anthropogenic end-member is best represented by the collected waters overflowing in the Seine River during heavy rain events (noted CSO hereafter, for combined sewer overflow). This material is made up of $27 \%$ of organic matter carried by urban waste waters, mixed with rain waters. The high $\mathrm{Pb}$ EF of the CSO samples is consistent with the affinity of $\mathrm{Pb}$ for organic matter (Balabane and van Oort, 2002, Pernet-Coudrier et al., 2011). Urban runoffs have been shown to contain high $\mathrm{Pb}$ concentration, together with $\mathrm{Zn}$ and $\mathrm{Cu}$ (Gromaire-Mertz et al., 2001). The ${ }^{206} \mathrm{~Pb} /{ }^{207} \mathrm{~Pb}$ ratio of the $\mathrm{CSO}\left({ }^{206} \mathrm{~Pb} /{ }^{207} \mathrm{~Pb}=1.1573 \pm 0.0025\right)$ corresponds to the urban signature determined by analyzing the WWTP effluent collected in $2006\left({ }^{206} \mathrm{~Pb} /{ }^{207} \mathrm{~Pb}=1.154 \pm\right.$ 0.002, Ayrault et al., 2012). It represents a mixing between the historical $\mathrm{Pb}$ accumulated since the $19^{\text {th }}$ century and "gasoline" $\mathrm{Pb}$. We note that the range of ${ }^{206} \mathrm{~Pb} /{ }^{207} \mathrm{~Pb}$ ratio covered by CSO is narrower than the range found in the Bouafles sediments throughout the $20^{\text {th }}$ century (Fig. 2). This suggests that $\mathrm{Pb}$ transported nowadays by the Seine River is produced by a thorough mixing between historical and gasoline lead, mixing that displayed a steady signature over the last decade. This implies that 20 years after the complete ban of leaded gasoline in France, gasoline $\mathrm{Pb}$ still contributes to the $\mathrm{Pb}$ contamination in the Seine River. There is a significant scattering of the CSO samples and of the different types of SPM data 
394 below the urban-natural mixing line. This scattering is likely due to the involvement of punctual sources in Paris intra muros that have not been completely homogenized. Nevertheless, the observed scattering is generally smaller than the change in isotopic ratio observed in the Seine River sediment during the 20th century and recorded in the B1 core.

The isotopic signature of suspended particles collected in the river nearby the core sampling site can be compared to top-core sediments. The upstream Seine River core TR01 samples (covering the 1970-2002 period) are plotted on a mixing line between urban lead and natural lead (Ayrault et al., 2012). The recent TR01 sample signature $(1.175 \pm 0.003$ in 2001) is consistent with the signature found in Marnay SPM. Unfortunately, Al or Sc was not measured on core TR01 samples, preventing calculation of the EF. For the 1994-2003 period, the downstream Seine River core B1 samples are plotted on a mixing line between urban lead and natural lead (Fig. 2). For the 1994-2003 period, the downstream Seine River core B1 samples are plotted on a mixing line between urban lead and natural lead (Fig. 2) with a $206 \mathrm{~Pb} / 207 \mathrm{~Pb}$ ratio of $1.166 \pm 0.004$ in 2003, a signature on the high boundary (but not significantly different) of the downstream Seine River sites Bougival and Triel (with comparable EF).

\subsection{Temporal variability of lead sources in the Orge River}

For the Orge River catchment, lead concentrations were found to be 2 to 6 times higher in SPM than the natural local background $(20 \mathrm{mg} / \mathrm{kg}$ ) and to be a function of the urbanization density (Le Pape et al., 2013) (Table 4, Fig. 3). The trends indicated a change in the lead contamination origin during the last decade. Indeed, the lead fingerprints evolved from a three-end member system (natural + urban + gasoline) to a two-end member one (natural + urban) (Fig. 3), corresponding to the end of lead gasoline supply to the river (Le Pape et al., 2013). These results highlighted the consequences of gasoline-lead ban in France (2000), as already observed in the Seine River basin (Ayrault et al., 2012). The lack of ${ }^{206} \mathrm{~Pb} /{ }^{207} \mathrm{~Pb}$ ratio lower than the urban signature in the SPM of the Orge River, a small and partly channelized urban catchment, could be explained by a faster turnover of sediments compared to one in the Seine River watershed that presents depositional areas allowing transitory to long term storage of particles. In a ${ }^{206} \mathrm{~Pb} /{ }^{207} \mathrm{~Pb}$ vs $1 / E F$ diagram, the $2010 / 2011$ Orge SPM samples correspond to the same mixing trend as the one observed at the Seine basin scale, with most samples falling slightly below the urban-natural mixing line (Le Pape et al., 2013). The Orge SPM displays a larger scattering 
below the urban-natural mixing line. During the high waterflow, the 2010/2011 SPM samples contamination displayed a clear upstream $\left({ }^{206} \mathrm{~Pb} /{ }^{207} \mathrm{~Pb}=1.177 \pm 0.002\right)$ to downstream $\left({ }^{206} \mathrm{~Pb} /{ }^{207} \mathrm{~Pb}=1.158 \pm 0.002\right)$ trend matching the urbanization trend, suggesting a shift from a diffuse source of lead to an urban contamination. During low waterflow, no clear pattern appears in the upstream to downstream signature trend. This may be attributed to local urban runoff releases occurring during low waterflow periods, as shown in Le Pape et al. (2013). The behavior of the Orge River bed sediment is clearly different from that of the SPM. Whatever the hydrodynamics of the river, the upstream to downstream signature trend did not follow the urbanization gradient, with the most upstream, less urbanized, site " $\mathrm{D}$ " signature varying from ${ }^{206} \mathrm{~Pb} /{ }^{207} \mathrm{~Pb}=1.165 \pm 0.002 ; 40.5 \mathrm{mg} / \mathrm{kg}$ to ${ }^{206} \mathrm{~Pb} /{ }^{207} \mathrm{~Pb}=1.150 \pm 0.002 ; 70.9 \mathrm{mg} / \mathrm{kg}$; lying between the "historical" and the "urban" end-members. In the Orge River, the ratio ${ }^{206} \mathrm{~Pb} /{ }^{207} \mathrm{~Pb}$ is never higher than $1.179 \pm 0.002(\mathrm{~Pb}=54.8 \pm 2.7 \mathrm{mg} / \mathrm{kg}$, site D) at the most upstream, less urbanized, site. These ${ }^{206} \mathrm{~Pb} /{ }^{207} \mathrm{~Pb}$ ratios remain significantly below the natural ${ }^{206} \mathrm{~Pb} /{ }^{207} \mathrm{~Pb}$ ratio and similar to the recent TR01 upstream core sample signature $(1.175 \pm 0.003$ in 2001$)$. Their signature is also close to the one of material collected in upstream Seine River sections even though they contain a higher $\mathrm{Pb}$ concentration. It might suggest the implication of a pervasive contamination by an anthropogenic $\mathrm{Pb}$ source that is more radiogenic than the gasoline additives, at the scale of the Orge River watershed. Studying A horizons collected each year at Versailles (15 km from Paris, $20 \mathrm{~km}$ from the Orge River watershed) from 1929 to 2000, Semlali et al. (2004) demonstrated that more than half of the anthropogenic $\mathrm{Pb}$ present nowadays in the topsoil was deposited before 1928. It has an isotopic signature ${ }^{206} \mathrm{~Pb} /{ }^{207} \mathrm{~Pb} \sim 1.18$ (the ratio in the 1929 soil is ${ }^{206} \mathrm{~Pb} /{ }^{207} \mathrm{~Pb}=1.183 \pm 0.001$ ) and it could be related to coal combustion, coal used in Europe having a ${ }^{206} \mathrm{~Pb} /{ }^{207} \mathrm{~Pb}$ ratio very close to 1.18 (Komarek et al., 2008; Chiarada et al., 2000; MacKinnon et al., 2011; Semlali et al., 2004). This is in agreement with other European studies that attributed the value of 1.18 to a "pre-gasoline" anthropogenic signature (Farmer et al., 2000; MacKinnon et al, 2011; Catinon et al., 2013). In a study dedicated to agricultural soils in the UK, MacKinnon et al. (2011) observed that despite the proximity to motorway and roads, non- gazoline $\mathrm{Pb}$ from historical, industrial and coal-burning emissions was the dominant component except for very limited areas located in the immediate vicinity of roads.

Although $\mathrm{Pb}$ isotopic signature in soils seems to be significantly affected by coal combustion and industrial fallout during the $19^{\text {th }}$ century, the Seine River SPM collected at downstream floodplain sites during most of the $20^{\text {th }}$ century are largely dominated by the Rio Tinto signature (Ayrault et al., 2012) with no significant contribution of a "coal" signature. To document this apparent contradiction, a detailed study of the $\mathrm{Pb}$ concentration, isotopic signature and lability is 
461 462 463

464 465

currently performed in the Orge River catchment, with a special attention paid to the different soil types and horizons. This scheme will be further extended to the entire Seine River basin.

\subsection{Lead-bearing particles in the river}

The possible relationship between the grain size and the $\mathrm{Pb}$ isotopic signature was investigated using the Orge River sampling campaign Jan 2011 (high waterflow) bed sediment. For this campaign, the SPM signature exhibits a clear upstream to downstream trend. We assumed that SPM originate from the BS finest fractions through resuspension of the bed sediment as it represents the major contamination pathway of the water column (Chon et al., 2012). Except at the most urbanized site where BS can be sampled (Y) (where the three fractions display similar signatures), the analyses of the sieved fractions showed that the signature of the different grain size fractions varied randomly from one site to the next (Table 5, Fig. 4). The finest fraction $(<63 \mu \mathrm{m})$ is the most contaminated one (up to $110 \mathrm{mg} / \mathrm{kg}$ at the most urbanized site $\mathrm{Y}$ ). However, because the coarser fractions ( $>63 \mu \mathrm{m}$ and $>200 \mu \mathrm{m}$ ) provide the bulk of the total mass of the BS samples, these coarse fractions bear a significant part of the $\mathrm{Pb}$ content (up to $72 \%$ of $\mathrm{Pb}$ is recovered in the $>200 \mu \mathrm{m}$ fraction at site $\mathrm{Y}$ ).

\section{Table 5, Figure 4}

The comparison of the signature of SPM versus BS as a function of river hydrodynamics is given in Fig. 5. It tends to show that during low waterflow, SPM signature tends to be closer to the "natural" end-member than the BS signature, whereas during high waterflow, the SPM signature is on average closer to the urban end-member than the BS one. This clearly supports the hypothesis of a BS resuspension during high waterflow conditions.

\section{Figure 5}

Lead ${ }^{206} \mathrm{~Pb} /{ }^{207} \mathrm{~Pb}$ ratio was also measured in "road deposit sediments" (RDS), corresponding to sediments sampled in a road gutter at a strongly urbanized site $\left(8000 \mathrm{inh} / \mathrm{km}^{2}\right)$. The result $\left({ }^{206} \mathrm{~Pb} /{ }^{207} \mathrm{~Pb}=1.144 \pm 0.003\right.$, Table 4) revealed the remanence of leaded gasoline in this sample that is mainly composed of coarse grains (Le Pape et al., 2013). In the UK, RDS exhibited signatures ranging from 1.13 to 1.145 (2001 samples) and 1.14 to 1.17 (2010 samples) (Mac Kinnon et al., 2012). The persistent leaded gasoline pollution at places where urban dust accumulated over decades was progressively leached by runoff over long periods of time 
contributing to the contamination of the bed sediment. Moreover, our results show that there is no direct contamination of the SPM from the RDS. This is consistent with the results of Catinon et al. (2013) showing that dust coarse fraction (200-2000 $\mu \mathrm{m})$ trapped in an outdoor urban building for 40 years have similarly conserved the memory of the gasoline lead contamination $\left({ }^{206} \mathrm{~Pb} /{ }^{207} \mathrm{~Pb}==1.146 \pm 0.002\right)$.

SEM analysis of the lead-bearing particles in the Seine River bed sediment showed the presence of coarse particles (> $50 \mu \mathrm{m}$, up to $200 \mu \mathrm{m}$ ) bearing $\mathrm{Pb}$ and evidencing an anthropogenic origin (alloys, quartz particles covered with a thin layer of $\mathrm{Pb}$; Priadi, unpublished results). The results on the Orge River sediments analyses are similar (Le Pape et al., 2013), showing Pb-containing paint chips (\# $20 \mu \mathrm{m}$ ) whereas the finest particles (Pb-phosphates; \# $5 \mu \mathrm{m}$ ) are provided by soil erosion. Unfortunately, SEM analyses only do not permit to conclude on lead isotopic signature in those particles.

The lead contamination on coarse particles observed by SEM, and the isotopic signature measured on the RDS, which mainly contained coarse particles outline a difference compared to results of previous studies exhibiting that exogenous $\mathrm{Pb}$ is linked to very fine particles, such as the clay fraction (Semlali et al., 2001; Sutherland et al., 2003). However, those studies were investigating diffuse atmospheric contamination due to gasoline emissions, whereas urban rivers receive water-transported anthropogenic $\mathrm{Pb}$ from different origins (gasoline, paints, alloys...). Sediment sieving to $50 \mu \mathrm{m}$ or $63 \mu \mathrm{m}$ conventionally performed in river contamination studies may then lead to the loss of this coarse fraction, which seems to play an important role in both the urban Orge River Pb transport and contamination. Further studies would be necessary to evaluate if this observation is applicable to other urban with varying geological characteristics.

\subsection{Towards a river contamination mixing scheme.}

Leaded gasoline additives have been significantly used from the 1950s, with a maximum of emissions in 1971 (Ferrand et al., 1999). From 1970 to 1990, successive regulations reduced lead concentration in gasoline. The leaded gasoline was progressively replaced with unleaded gasoline from 1990 to 2000. Lead from gasoline was intensively emitted for 30 years, from 1960 to 1990 at a rate of 5000 to $12000 \mathrm{t}$ per year (roughly 1500 to $3500 \mathrm{t}$ per year for the Seine River basin).

Here, we compare the flux of "gasoline" $\mathrm{Pb}$ transported by the river to the flux of "gasoline" $\mathrm{Pb}$ emitted over the Seine Basin in 1986, when the gasoline contribution was the highest in the 
529 Seine River sediment. The flux of "gasoline" $\mathrm{Pb}$ transported by the Seine is given by:

$530 \quad F_{\text {gazolinePb-river }}=f^{*} P b^{*} F_{\text {particles }}=26 \pm 7$ ton/y, where $f$ is the fraction of $\mathrm{Pb}$ in the sediment derived 531 from gasoline $(\approx 23 \pm 6 \%), P b$ is the total concentration of $\mathrm{Pb}$ in the sediment $(\approx 153 \pm 18 \mathrm{mg} / \mathrm{kg})$ 532 in 1986 downstream Paris and the Seine-Aval WWTP at the Muids and Bouafle sites (Ayrault et 533 al., 2012). $F_{\text {particles }}$ is the annual flux of particles ( $\approx 750$ ton/y, Meybeck et al., 1998).

534 Assuming that the Seine River basin receives 25\% (Saby et al., 2006) of the 7500 tons of 535 gasoline $\mathrm{Pb}$ emitted in France in 1986 (Ferrand et al., 1999), the emission flux $F_{\text {gazolinePb-emission }}$ is 536 estimated to1900 tons.

537 Hence, the river exports only $1.4 \%$ of the gasoline $\mathrm{Pb}$ deposited annually. It implies that most of 538 the gasoline $\mathrm{Pb}$ remains stored in the soils of the Seine River basin. Nevertheless, gasoline $\mathrm{Pb}$ is 539 removed much more efficiently than ${ }^{210} \mathrm{~Pb}$, a natural $\mathrm{Pb}$ radionuclide supplied homogeneously 540 over the basin by rainfall, for which only $0.7 \%$ of the annual deposit reaches the estuary (Le 541 Cloarec et al., 2007). Indeed, natural ${ }^{210} \mathrm{~Pb}$ is deposited homogeneously over the whole Seine 542 River Basin, whereas gasoline $\mathrm{Pb}$ is mostly deposited around Paris (the bulk of gasoline fallout occurred within a distance of 60-100 km from Paris, Saby, 2006). In this context, gasoline $\mathrm{Pb}$ would have $2.0 \pm 0.5$ times more chance to reach the river than ${ }^{210} \mathrm{~Pb}$, due to the larger proportion of impermeable surfaces directly connected to the river in Paris and in its close suburbs compared to the rest of the basin.

\section{Figure 6}

This does not imply that lead from gasoline has been completely and definitely flushed from the Seine River basin, even in urban areas. The fast decrease of leaded gasoline contribution to the river contamination after the emissions stopped may be attributed to the fact that the leaded gasoline was mainly emitted in the most urban areas and along the roads (MacKinnon et al., 2011). Soil erosion affecting areas connected to the river network and runoff on urban surfaces supply fine particles contaminated in $\mathrm{Pb}$ to the watercourses during heavy rainfall (Fig. 6). 556 However, because of the strong affinity of $\mathrm{Pb}$ for organic matter (e.g., Semlali et al., 2001, 557 Balabane et al., 2002) and the low erosion rates recorded in the Seine River basin, the residence 558 time of this contaminant in soils is very long (up to 10,000 years, Le Cloarec et al., 2007). 
560 may constitute a sink for atmospheric anthropogenic $\mathrm{Pb}$ which would therefore exert a low but 561 continuous pressure on the river water quality. When the river flows across the Paris megacity, 562 the huge amount of $\mathrm{Pb}$ accumulated in the city infrastructure (pipes, roofs, ...) imprints the 563 signature of the Rio Tinto ore (the "historical" $\mathrm{Pb}$ ) on the sediment transiting in the downstream sections of the river.

\section{Conclusions}

\section{Acknowledgements}

This extensive study of the $\mathrm{Pb}$ composition in the river sediments allows to infer the spatial and temporal variability of the anthropogenic $\mathrm{Pb}$ sources in the Seine River basin. In the upstream part of basin, before the river flows across the Paris megacity, most of the current $\mathrm{Pb}$ river contamination is supplied by soil erosion that stores anthropogenic contamination that has accumulated since the $19^{\text {th }}$ century. Further studies are needed to elucidate the origin of this pervasive soil contamination. The large contamination depth associated with the long residence time of the particles in the soil complicates the detection of any decontamination trend in the basin soils at the decadal scale. To evaluate precisely this "background" contamination, a detailed study of the natural concentration and isotopic signature of the different lithologies and soil types present in the basin is required.

In the downstream part of the river under strong urban influence, the contamination is mainly due to the release of the so-called "urban" $\mathrm{Pb}$ whose signature results from a thorough mixing of "historical" and "gasoline" $\mathrm{Pb}$. Urban $\mathrm{Pb}$ exhibits a remarkably steady signature over time and space, even though a progressive decrease in the gasoline contribution could have been expected after the ban of leaded additives. It appears that, after the first flush of the gasoline $\mathrm{Pb}$ within the decade that followed the ban, a significant part of the gasoline $\mathrm{Pb}$ emitted in the basin had transformed into an "urban alloy". Further studies coupling solid speciation tools and isotopic studies at the scale of particles would help in characterizing the bearing phases and availability of the urban lead.

The authors would like to thank Louise Bordier (LSCE) for sampling and analytical assistance with ICP-MS measurements and Rémy Pichon (IDES) for SEM-EDX observations (Orge River samples). They are also grateful to William Thomas (Service de Navigation de la Seine) for providing the Seine River bed sediments. This work was supported by the EC2CO/CYTRIX-CNRS/INSU Programme, by PIREN Seine programme and by the French 
Ministry of National Education and Research.

\section{References}

Alfonso S, Grousset F, Massé L, Tastet JP (2001) A European lead isotope signal recorded from 6000 to 300 years BP in coastal marshes (SW France). Atmos Environ 35:3595-605

Ayrault S, Rianti C, Evrard O, Lefèvre I, Bonté P (2010) Silver and thallium historical trends in the Seine River basin. J Environ Monitor 12:2177-2185

Ayrault S, Roy-Barman M, Le Cloarec MF, Priadi C, Bonté P, Göpel C (2012) Lead contamination of the Seine River, France: geochemical implications of a historical perspective. Chemosphere 97:902-910

Bacon JR, Jones KC, Mc Grath SP, Johnston AE (1996) Isotopic character of lead deposited from the atmosphere at a grassland site in the United Kingdom since 1860. Environ Sci Technol 30:2511-2518

Balabane M, van Oort F (2002). Metal enrichment of particulate organic matter in arable soils with low metal contamination. Soil Biology and Biochemistry 34, 1513-1516.

Bonte P, Mouchel JM, Thomas A, Le Cloarec MF, Dumoulin JP, Sogon S, Tessier L (2000) Buffering of suspended sediment transport in lowland river during low water stages: quantification in river Seine using environmental radionuclides. Acta Geol Hisp 35:339-355.

Catinon M, Ayrault S, Boudouma O, Asta J, Tissut M, Ravanel P (2013) Are coarse particles unexpected common reservoirs for some atmospheric anthropogenic trace elements? A case study. Atmos Environ 74:217-226

Chiaradia M, Cupelin FF (2000) Behaviour of airbone lead and temporal variations of its source effects in Geneva (Switzerland): comparison of anthropogenic versus natural processes. Atmos Environ 34:959-971.

Chon HS, Ohandja DG, Voulvoulis N (2012) The role of sediments as a source of metals in river catchments. Chemosphere 88:1250-1256.

Elbaz-Poulichet F, Holliger P, Martin JM, Petit D (1986) Stable lead isotopes ratios in major French rivers and estuaries. Sci Total Environ 54:61-76.

Ferrand JL, Hamelin B, Monaco A (1999) Isotopic tracing of anthropogenic Pb inventories and sedimentary fluxes in the Gulf of Lions (NW Mediterranean sea). Cont Shelf Res 19:23-47.

Farmer, JG, Broadway, A, Cave, MR, Wragg, J, Fordyce, FM, Graham, MC, Ngwenya, BT, Bewley, RJF, 2011, A lead isotopic study of the human bioaccessibility of lead in urban soils from Glasgow, Scotland. Sci Total Environ 409:4958-4965.

Graham MC, Vinogradoff S, Chipchase A, Dunn S, Bacon J, Farmer J (2006) Using Size Fractionation and $\mathrm{Pb}$ Isotopes to Study $\mathrm{Pb}$ Transport in the Waters of an Organic-Rich Upland Catchment. Environ. Sci. Technol. 40:1250-1256

Gromaire-Mertz MC; Garnaud S; Saad M; Chebbo G (2001) Contribution of different sources to the pollution of wet weather flows in combined sewers. Water Res. 35(2):521-533 
Grosbois C, Meybeck M, Lestel L, Lefèvre I and Moatar F (2012) Severe and contrasted polymetallic contamination patterns (1900-2009) in the Loire River sediments (France). Sci Total Environ 435-436:290-305

Horowitz A, Elrick KA (1987) The relation of stream sediments surface area, grain-size and composition of trace element chemistry. Appl Geochem 2(4):437-51

Kachur AN, Arzhanova VS, Yelpatyevsky PV, von Braun MC, von Lindern IH (2003) Environmental conditions in the Rudnaya River watershed - a compilation of Soviet and post-Soviet era sampling around a lead smelter in the Russian Far East. Sci Total Environ 303:171-185

Komarek M, Ettler V, Chrastny V, Mihaljevic M (2008) Lead isotopes in environmental sciences: a review. Environ Int 34:562-577

Le Cloarec MF, Bonté P,Mouchel JM, Lefèvre I, Colbert SL (2007) Distribution of ${ }^{7} \mathrm{Be},{ }^{210} \mathrm{~Pb}$ and ${ }^{137} \mathrm{Cs}$ in watersheds of different scales in the Seine River basin: inventories and residence times Sci Total Environ 375:125-39

Le Pape P, Ayrault S, Quantin C (2012) Multivariate analysis of trace metal geochemistry in the water column of the urban Orge River, France. J Hydrol 472-473:99-110

Le Pape P, Ayrault S, Michelot J-L, Monvoisin G, Noret A, Quantin C (2013) Building an isotopic hydro-geochemical indicator of anthropogenic pressure on urban rivers. Chem Geol 334:63-72

Luck JM, Ben Othman D (1998) Geochemistry and water dynamics II Trace metals and Pb-Sr isotopes as tracers of water movements and erosion processes. Chem Geol 150:263-282

Marcoux E (1998) Lead isotope systematics of the giant massive sulphide deposits in the Iberian Pyrite Belt. Miner Deposita 33:45-58

MacKinnon G, MacKenzie AB, Cook GT, Pulford ID, Duncan HJ, Scott EM (2011) Spatial and temporal variations in $\mathrm{Pb}$ concentrations and isotopic composition in road dust, farmland soil and vegetation in proximity to roads since cessation of use of leaded petrol in the UK. Sci Total Environ 409: 5010-5019

Meybeck M, de Marsily G, Fustec E (1998) La Seine en son bassin, Fonctionnement écologique d'un système fluvial anthropisé Paris:Elsevier ISBN 2-84299-058-7; 749 pp

Meybeck M, Horowitz A, Grosbois C (2004) The geochemistry of the Seine River Basin particulate matter Distribution patterns of an integrated metal pollution index. Sci Total Environ 328:219-36

Meybeck M, Lestel L, Bonté P, Moilleron R, Colin JL, Rousselot O, et al (2007) Historical perspective of heavy metals contamination $(\mathrm{Cd}, \mathrm{Cr}, \mathrm{Cu}, \mathrm{Hg}, \mathrm{Pb}, \mathrm{Zn})$ in the Seine River basin (France) following a DPSIR approach (1950-2005). Sci Total Environ 375:204-31

Miller JR, Lechler PJ, Mackin G, Germanoski D, Villarroel Lionel F (2007) Evaluation of particle dispersal from mining and milling operations using lead isotopic fingerprinting techniques, Rio Pilcomayo Basin, Bolivia. Sci Total Environ 384:355-373

Monna F, Clauer N, Toulkeridis T, Lancelot JR (2000) Influence of anthropogenic activity on the lead isotope signature of Thau Lake sediments (southern France): origin and temporal evolution. Appl Geochem 15:1291-1305 
Négrel P and Grosbois C (1999) Changes in chemical and 87Sr/86Sr signature distribution patterns of suspended matter and bed sediments in the upper Loire river basin (France). Chem Geol 156:231-249

Pacyna JM, Pacyna EG (2000) Atmospheric emissions of anthropogenic lead in Europe: improvements, updates, historical data and projections 200 GKSS Research Center, p 31

Passerat J, Ouattara NK, Mouchel JM, Rocher V, Servais P (2011) Impact of an intense combined sewer overflow event on the microbiological water quality of the Seine River. Wat Res 45(2):893-903

Pernet-Coudrier, B, Companys E, Galceran J, Morey M, Mouchel JM, Puy J, Ruiz N, Varrault G (2011) Pb-binding to various dissolved organic matter in urban aquatic systems: Key role of the most hydrophilic fraction. Geochim Cosmochim Acta 75(14):4005-4019

Priadi C, Bourgeault A, Ayrault S, Gourlay-Francé C, Tusseau-Vuillemin M-H, Bonté P, Mouchel J-M (2011a) Spatio-temporal variability of solid, total dissolved and labile metal: passive vs discrete sampling evaluation in river metal partitioning. J Environ Monitor 13:1470-1479

Priadi C, Ayrault S, Pacini S, Bonté P (2011b) Urbanization impact on metal mobility in riverine suspended sediment: Role of metal oxides. Int J Environ Sci Technol 8(1):1-18

Reimann C, de Caritat P (2005) Distinguishing between natural and anthropogenic sources for elements in the environment: regional geochemical surveys versus enrichment factors. Sci Tot Environ 337:91-107

Semlali RM, van Oort F, Denaix L, Loubet M (2001) Estimating distributions of endogenous and exogenous $\mathrm{Pb}$ in soils by using $\mathrm{Pb}$ isotopic ratios. Environ Sci Technol 35:4180-8

Semlali RM, Dessogne JB, Monna F, Bolte J, Azimi S, Navarro N, Denaix L, Loubet M, Château C, van Oort F (2004) Modeling Lead Input and Output in Soils Using Lead Isotopic Geochemistry Environ Sci Technol 38:1513-1521

Shotyk W, Weiss D, Appleby P, Cheburkin A, Frei R, Gloor M, Kramers J, Reese S, Van Der Knapp W (1998) History of atmospheric lead deposition since 12,370 14C yr BP from peat bog, Jura Mountains, Switzerland. Science 281:1635-40

Sutherland RA, Day JP, Bussen JO (2003) Lead concentrations, isotope ratios and source apportionment in road deposited sediments, Honolulu, Oahu, Hawaii. Wat Air Soil Pollut 142:165-186

Thévenot DR, Moilleron R, Lestel L, Gromaire MC, Rocher V, Cambier P, Bonté P, Colin JL, de Pontevès C, Meybeck M (2007) Critical budget of metal sources and pathways in the Seine River basin (1994-2003) for Cd, Cr, Cu, Hg, Ni, Pb and Zn. Sci Total Environ 375:180-203

Véron A, Flament P, Bertho ML, Alleman L, Flegal R, Hamelin B (1999) Isotopic evidence of pollutant lead sources in Northwestern France. Atmos Environ 33:3377-88

Saby N, Arrouays D, Boulonne L, Jolivet C, Pochot A (2006) Geostatistical assessment of Pb in soil around Paris France. Sci Total Environ 367:212-221

Sun GX, Wang XJ, Hu QH (2011) Using stable lead isotopes to trace heavy metal contamination sources in sediments of Xiangjiang and Lishui Rivers in China. Environ Pollut 159:3406-3410

Stone M, Droppo IG (1996) Distribution of lead, copper and zinc in size-fractionated river bed 
1

2

718 sediment in two agricultural catchments of southern Ontario, Canada. Environ Pollut $719 \quad 93: 353-362$

720 Widory D (2004) Development of a method for characterising contributions of point sources to 721 atmospheric emissions of particles using a multi-isotopic approach: Application to the 722 urban area of Paris. Report BRGM/RP-53335-FR 


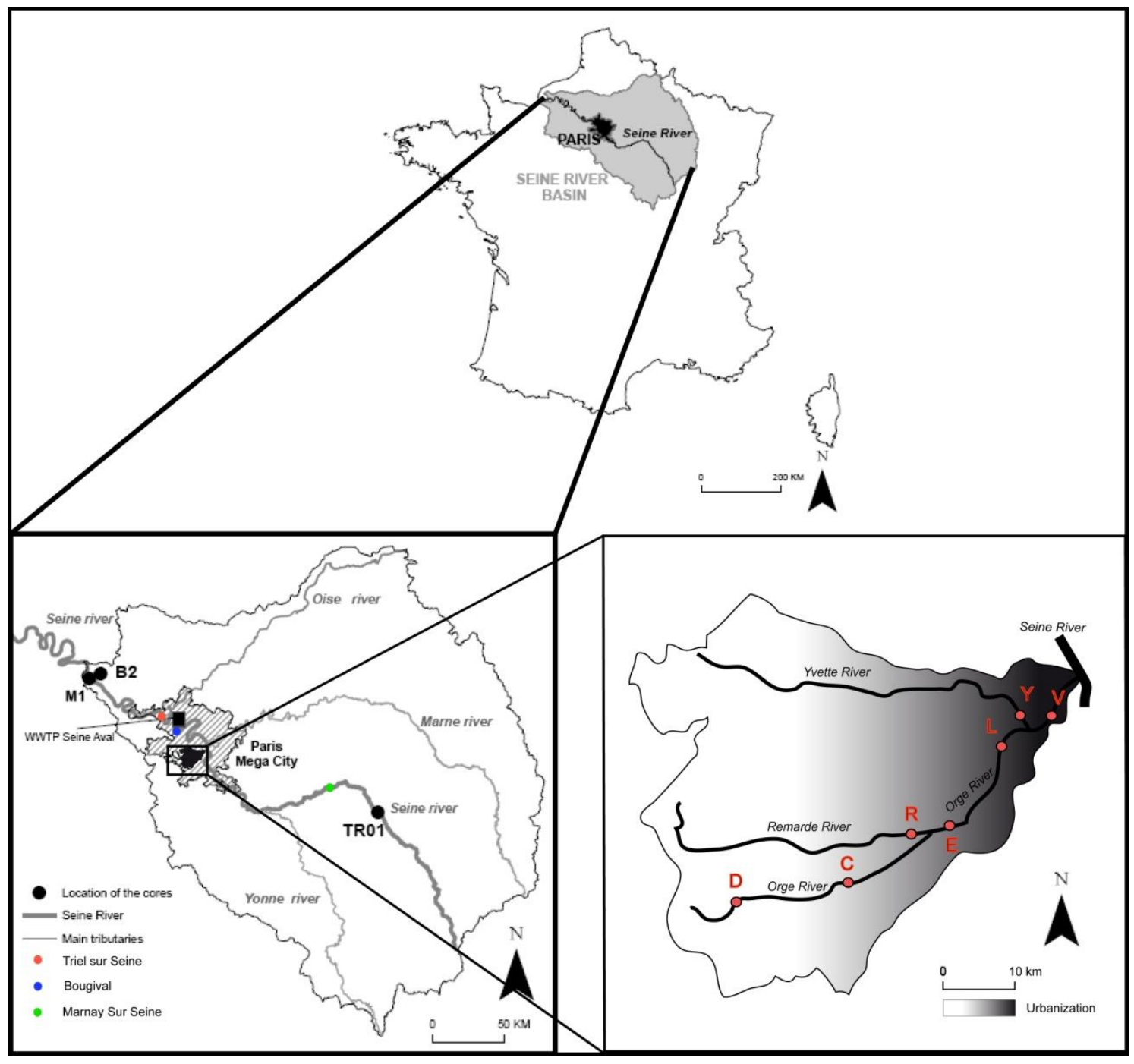

Figure 1. Location of the studied catchments. The Orge River catchment $\left(900 \mathrm{~km}^{2}\right)($ down, right) is a sub-catchment of the Seine River basin $\left(64,700 \mathrm{~km}^{2}\right)$ (down, left). See Table 1 for the sampling sites labels. 


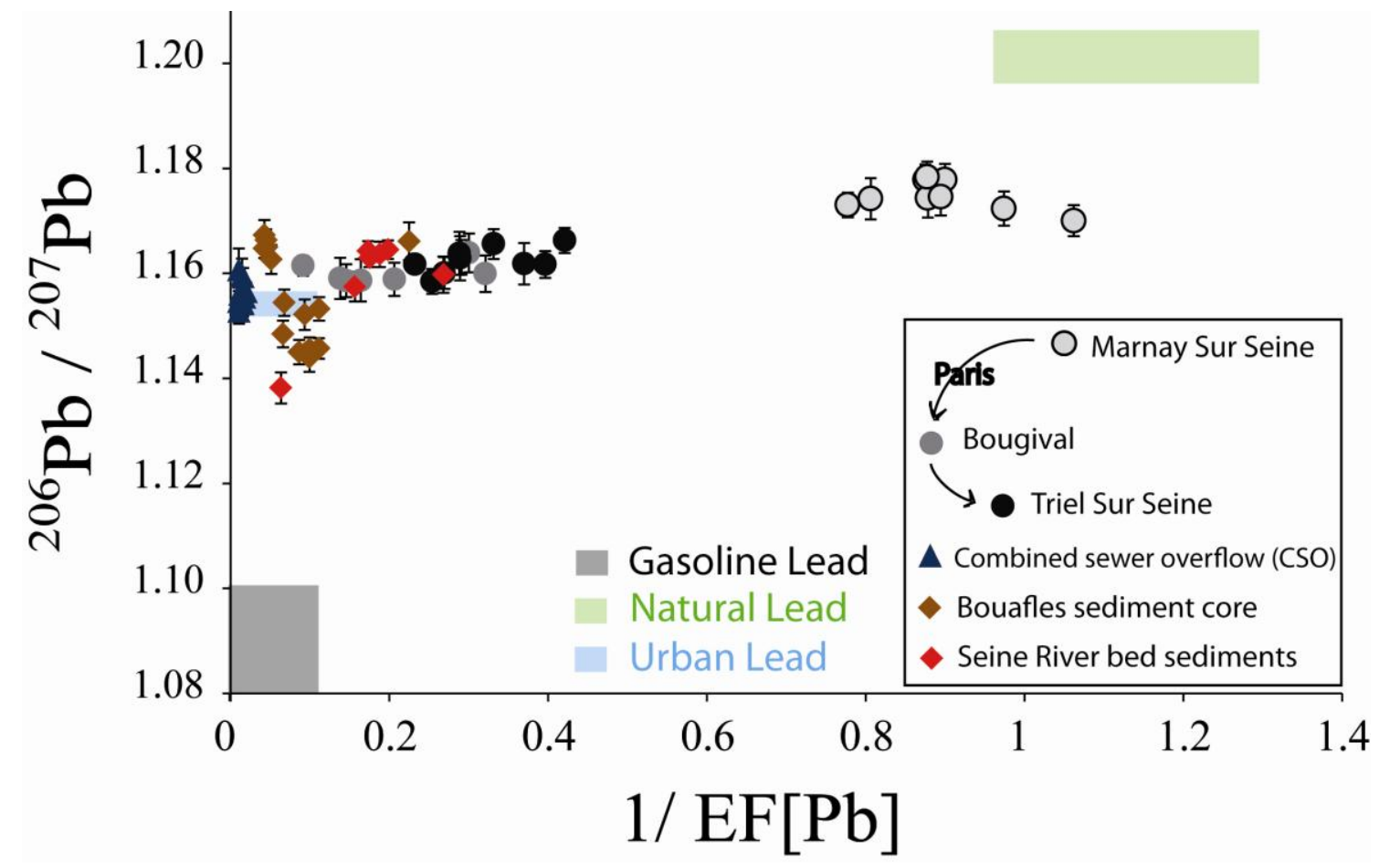

Figure 2. Isotopic $\mathrm{Pb}$ signature versus $1 / \mathrm{EF}$. $\mathrm{EF}$ : enrichment factor (see text). The colored arrays delimited end-member areas (blue for "urban" $\mathrm{Pb}$, gray for "gasoline" $\mathrm{Pb}$, green for "natural" $\mathrm{Pb})$. 

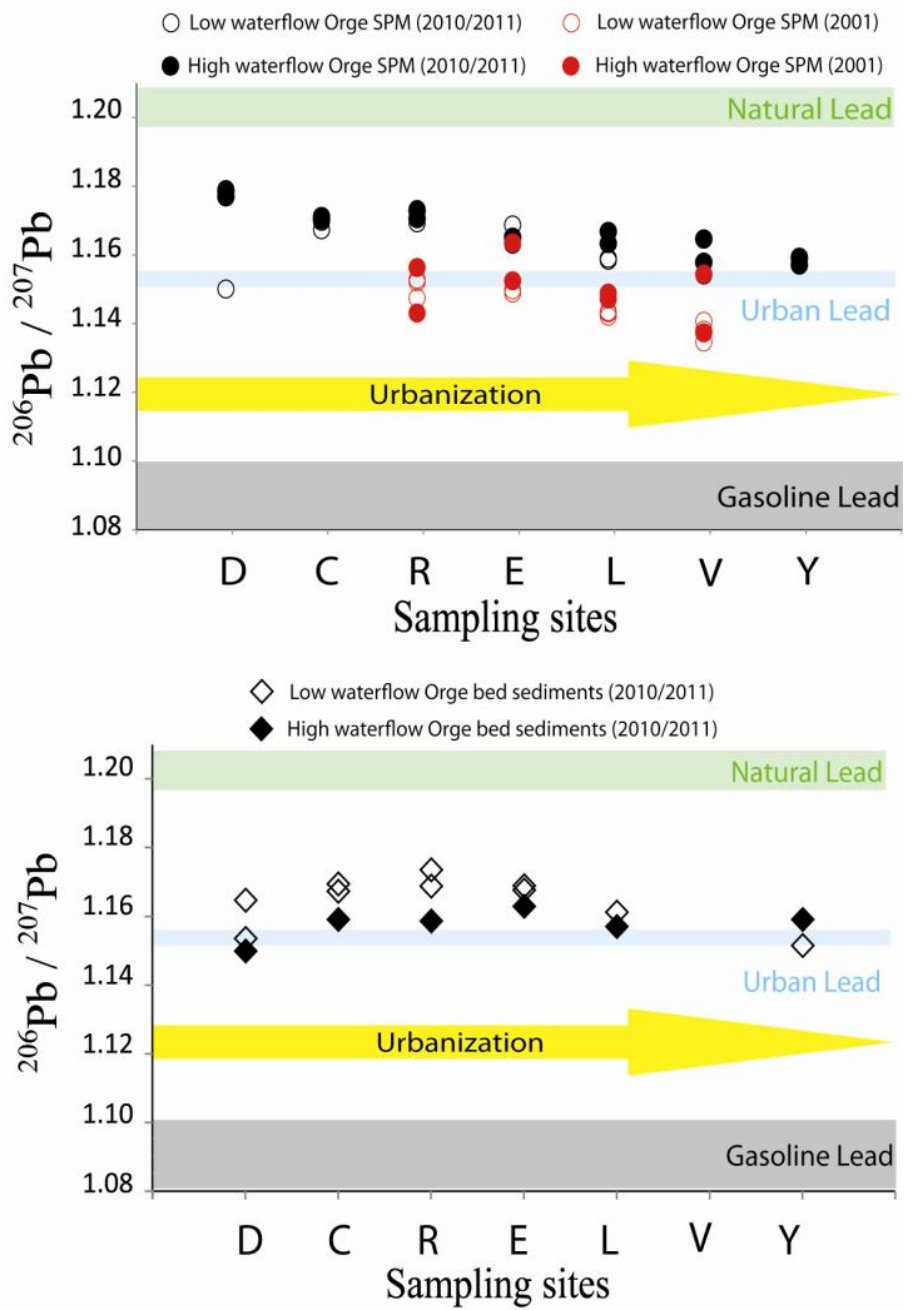

Figure 3. Isotopic $\mathrm{Pb}$ signature in suspended particle matter (SPM) (top) and bed sediments (BS) (down) of the Orge River. Open circles are for low water flow samplings. Closed circles are for high waterflow samplings. The symbol size matches the error amplitude. 


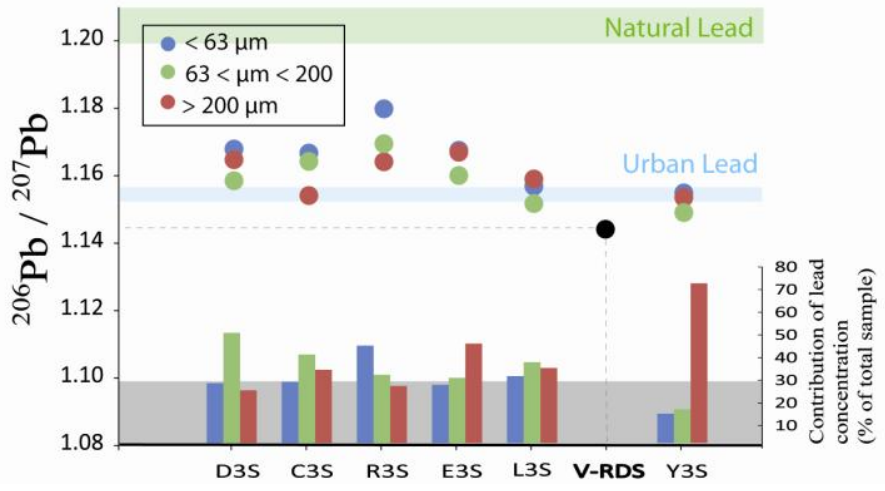

Figure 4. Isotopic $\mathrm{Pb}$ signature of the sieved bed sediments of the Orge River. RDS: road-side sediment sampled at V site. See Table 1 for the sites label. The symbol size matches the error amplitude. 


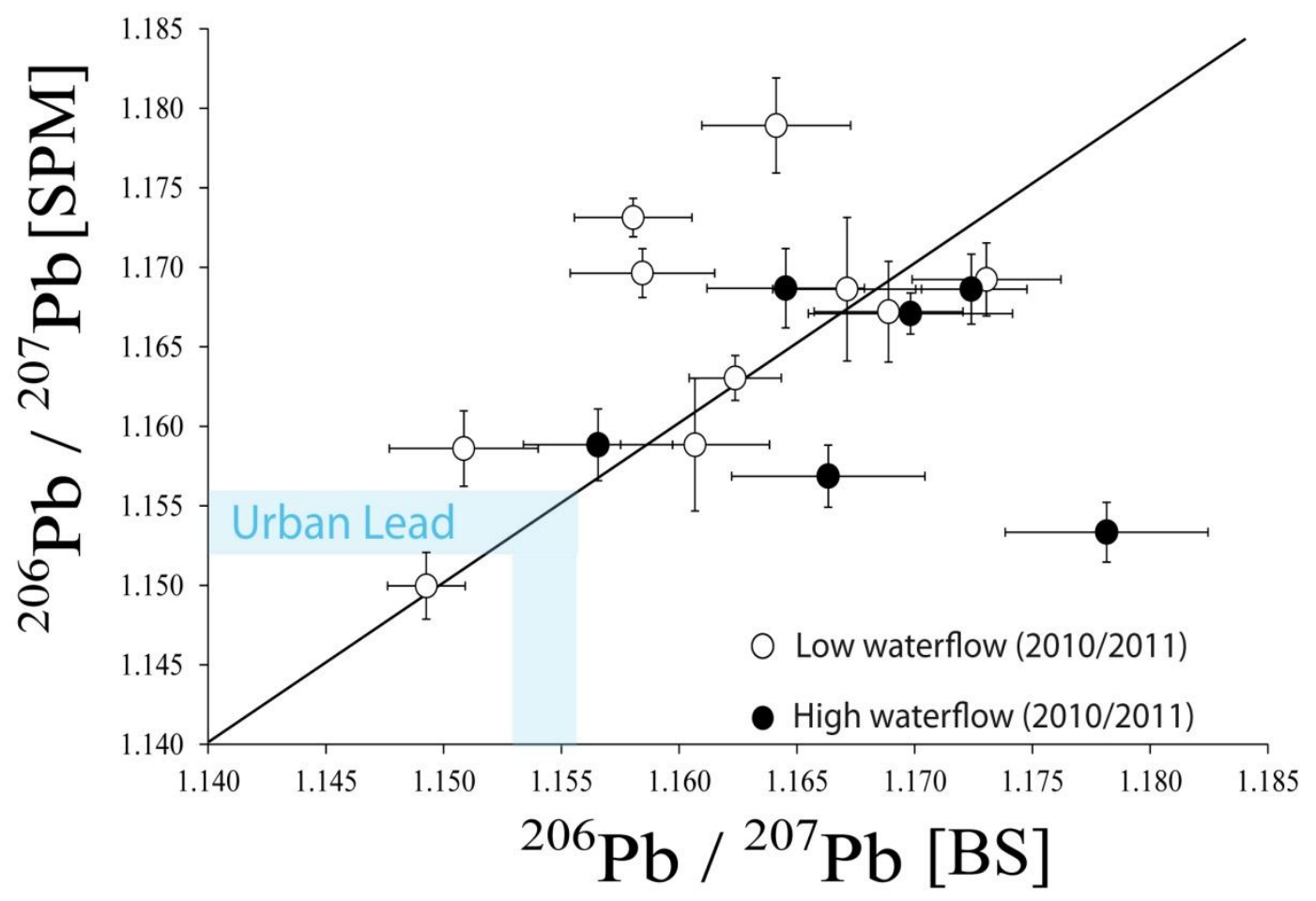

Figure 5. Isotopic $\mathrm{Pb}$ signature of the suspended particle matter (SPM) and bed sediments (BS) of the Orge River. Open circles are for low water flow samplings. Closed circles are for high waterflow samplings. 


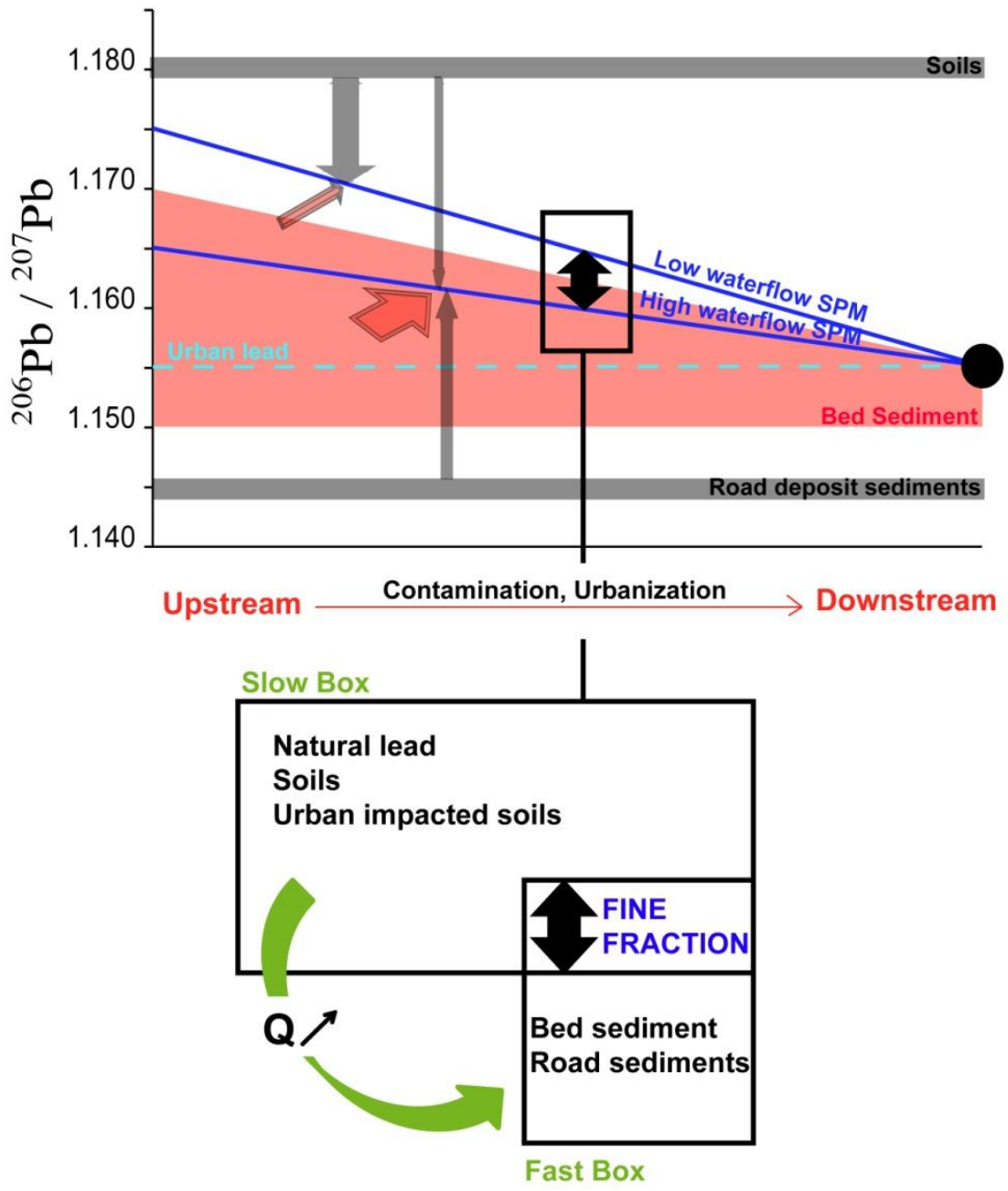

Figure 6. Scheme of the $\mathrm{Pb}$ contamination pathways along an urban river. 
Table 1. Sample types, location and period of collection.

\begin{tabular}{|c|c|c|c|c|}
\hline Site & Label & \multicolumn{2}{|c|}{ Lambert II coordinates } & Sampling date \\
\hline \multicolumn{5}{|l|}{ Seine } \\
\hline \multicolumn{5}{|c|}{ Bed sediments (provided by SNS) } \\
\hline Paris, Pt Tolbiac & Tol & 595770 & 2427906 & Sep 2007 \\
\hline Suresnes & Sur & 592144 & 2429828 & Sep 2007; Aug 2009 \\
\hline Sartrouville & Sar & 586939 & 2438517 & Jul 2008; Sep 2009 \\
\hline Colombes & Col & 591484 & 2435843 & Aug 2009 \\
\hline Clichy & Cli & 598131 & 2434990 & Aug 2009 \\
\hline \multicolumn{5}{|l|}{ Cores (Ayrault et al., 2012) } \\
\hline Troyes & TR01 & 726238 & 2372883 & Mar 1998 \\
\hline Muids & M1 & 525581 & 2470343 & Apr 2003 \\
\hline Bouafles & B2 & 529698 & 2468611 & Apr 2003 \\
\hline \multicolumn{5}{|l|}{ SPM (Priadi et al., 2011 a, b) } \\
\hline Marnay-sur-Seine & M & 690279 & 2391403 & Dec 2008 - Sept 2009 \\
\hline Bougival & B & 583671 & 2431778 & Jan 2009 - Sept 2009 \\
\hline Triel-sur-Seine & $\mathrm{T}$ & 575458 & 2442308 & Dec 2008 - Aug 2009 \\
\hline \multicolumn{5}{|c|}{ Combined sewer overflow (Passerat et al., 2013) } \\
\hline Clichy & $\mathrm{CSO}$ & 598131 & 2434990 & Aug 2008 \\
\hline \multicolumn{5}{|c|}{ Orge (Le Pape et al., 2012 and 2013) } \\
\hline \multicolumn{5}{|l|}{ SPM and bed sediment } \\
\hline Dourdan & $\mathrm{D}$ & 575202 & 2392697 & Jun 2010; Sep 2010; Jan 2011; Apr 2011 \\
\hline St Chéron & $\mathrm{C}$ & 584428 & 2394522 & Jun 2010; Sep 2010; Jan 2011; Apr 2011 \\
\hline Rémarde & $\mathrm{R}$ & 589402 & 2398180 & Jun 2010; Sep 2010; Jan 2011; Apr 2011 \\
\hline Egly & $\mathrm{E}$ & 591912 & 2398466 & 2001; Jun 2010; Sep 2010; Jan 2011; Apr 2011 \\
\hline Longpont-sur-Orge & $\mathrm{L}$ & 597093 & 2405080 & 2001; Jun 2010; Sep 2010; Jan 2011; Apr 2011 \\
\hline Yvette & Y & 599432 & 2408855 & Jun 2010; Sep 2010; Jan 2011; Apr 2011 \\
\hline Viry-Chatillon & $\mathrm{V}$ & 603074 & 2408773 & 2001; Jun 2010; Sep 2010; Jan 2011; Apr 2011 \\
\hline \multicolumn{5}{|l|}{ Road side dust } \\
\hline Viry-Chatillon & RDS & 603074 & 2408773 & Jan 2011 \\
\hline
\end{tabular}


Table 2. Seine River bed sediment data. The three first letters correspond to the label of the sampling site (see Table 1), the two last figures refer to the sampling year (see Table 1). EF: enrichment factor (see text).

\begin{tabular}{lrrrrr}
\hline & ${ }^{206} \mathrm{~Pb} /{ }^{207} \mathrm{~Pb}$ & $\pm 2 \mathrm{~s}$ & $\mathrm{Al}(\mathrm{mg} / \mathrm{kg})$ & $\mathrm{Pb}(\mathrm{mg} / \mathrm{kg})$ & \multicolumn{1}{c}{$\mathrm{EF}$} \\
\hline Tol 07 & $1.1645 \pm 0.0019$ & $30870 \pm 4320$ & $99.7 \pm 5.0$ & 5.8 \\
Sur 07 & $1.1600 \pm 0.0034$ & $36145 \pm 5060$ & $75.2 \pm 3.8$ & 3.7 \\
Sar 08 & $1.1632 \pm 0.0017$ & $29360 \pm 4110$ & $93.8 \pm 4.7$ & 5.8 \\
Sur 09 & $1.1639 \pm 0.0024$ & $24885 \pm 3485$ & $74.0 \pm 3.7$ & 5.4 \\
Col 09 & $1.1384 \pm 0.0030$ & $31580 \pm 4420$ & $281.7 \pm 14.1$ & 16.1 \\
Cli 09 & $1.1647 \pm 0.0018$ & $33910 \pm 4750$ & $95.5 \pm 4.8$ & 5.1 \\
Sar 09 & $1.1577 \pm 0.0028$ & $30370 \pm 4252$ & $108.5 \pm 5.4$ & 6.4 \\
\hline
\end{tabular}


Table 3. Seine River trapped SPM. EF: enrichment factor (see text).

\begin{tabular}{|c|c|c|c|c|}
\hline Sampling date & ${ }^{206} \mathrm{~Pb} /{ }^{207} \mathrm{~Pb} \pm 2 \mathrm{~s}$ & Al $(\mathrm{mg} / \mathrm{kg})$ & $\mathrm{Pb} \quad(\mathrm{mg} / \mathrm{kg})$ & $\mathrm{EF}$ \\
\hline \multicolumn{5}{|l|}{ Marnay (M) } \\
\hline $20 / 12 / 2008$ & $1.1777 \pm 0.0033$ & $36954 \pm 5174$ & $23.5 \pm 1.2$ & 1.14 \\
\hline $20 / 01 / 2009$ & $1.1781 \pm 0.0028$ & $34735 \pm 4863$ & $22.1 \pm 1.1$ & 1.14 \\
\hline $20 / 02 / 2009$ & $1.1744 \pm 0.0039$ & $29556 \pm 4138$ & $20.4 \pm 1.0$ & 1.24 \\
\hline 20/03/2009 & $1.1703 \pm 0.0030$ & $38998 \pm 5460$ & $20.4 \pm 1.0$ & 0.94 \\
\hline $20 / 04 / 2009$ & $1.1725 \pm 0.0033$ & $32687 \pm 4576$ & $18.7 \pm 0.9$ & 1.03 \\
\hline $10 / 06 / 2009$ & $1.1746 \pm 0.0037$ & $30757 \pm 4306$ & $19.5 \pm 1.0$ & 1.14 \\
\hline $22 / 06 / 2009$ & $1.1781 \pm 0.0030$ & $31796 \pm 4451$ & $19.7 \pm 1.0$ & 1.11 \\
\hline $20 / 07 / 2009$ & $1.1786 \pm 0.0030$ & $31552 \pm 4417$ & $20.0 \pm 1.0$ & 1.14 \\
\hline 20/08/2009 & $1.1748 \pm 0.0036$ & $31723 \pm 4441$ & $19.7 \pm 1.0$ & 1.12 \\
\hline 20/09/2009 & $1.1733 \pm 0.0023$ & $32090 \pm 4493$ & $23.0 \pm 1.1$ & 1.29 \\
\hline Median \pm SD & $1.1752 \pm 0.0028$ & & $20.7 \pm 1.6$ & \\
\hline
\end{tabular}

\section{Bougival (B)}

\begin{tabular}{rrrrrrrr}
$20 / 01 / 2009$ & 1.1591 & 0.0039 & 38862 & 5441 & 105.2 & 5.3 & 4.87 \\
$20 / 02 / 2009$ & 1.1601 & 0.0042 & 54900 & 7686 & 95.4 & 4.8 & 3.13 \\
$20 / 03 / 2009$ & 1.1633 & 0.0028 & 41725 & 5842 & 80.0 & 4.0 & 3.45 \\
$20 / 04 / 2009$ & 1.1641 & 0.0024 & 46881 & 6563 & 87.1 & 4.4 & 3.34 \\
$10 / 06 / 2009$ & 1.1617 & 0.0026 & 39883 & 5584 & 245.2 & 12.3 & 11.07 \\
$20 / 07 / 2009$ & 1.1593 & 0.0041 & 43563 & 6099 & 176.7 & 8.8 & 7.30 \\
$20 / 08 / 2009$ & 1.1588 & 0.0030 & 36609 & 5125 & 140.7 & 7.0 & 6.92 \\
$20 / 09 / 2009$ & 1.1589 & 0.0024 & 43416 & 6078 & 148.0 & 7.4 & 6.14 \\
\hline edian \pm SD & 1.1607 & 0.0021 & & & 134.8 & 2.8 &
\end{tabular}

Triel (T)

$\begin{array}{llllllll}20 / 12 / 2008 & 1.1621 & 0.0032 & 38909 & 5447 & 58.7 & 2.9 & 2.71 \\ 20 / 01 / 2009 & 1.1631 & 0.0035 & 42411 & 5938 & 81.8 & 4.1 & 3.47 \\ 20 / 02 / 2009 & 1.1658 & 0.0033 & 32886 & 4604 & 55.3 & 2.8 & 3.03 \\ 20 / 03 / 2009 & 1.1665 & 0.0037 & 38273 & 5358 & 50.7 & 2.5 & 2.38 \\ 20 / 04 / 2009 & 1.1619 & 0.0019 & 45352 & 6349 & 63.7 & 3.2 & 2.53 \\ 10 / 06 / 2009 & 1.1640 & 0.0040 & 43473 & 6086 & 84.1 & 4.2 & 3.48\end{array}$




\begin{tabular}{rrrrrrrr}
$22 / 06 / 2009$ & 1.1603 & 0.0031 & 39913 & 5588 & 82.7 & 4.1 & 3.73 \\
$20 / 07 / 2009$ & 1.1587 & 0.0040 & 40782 & 5709 & 89.6 & 4.5 & 3.96 \\
$20 / 08 / 2009$ & 1.1619 & 0.0041 & 40981 & 5737 & 98.5 & 4.9 & 4.33 \\
Median \pm SD & 1.1627 & \pm 0.0025 & & & 75.8 & \pm 0.9 & \\
\hline
\end{tabular}


Table 4. Combined sewer overflow (CSO) particulate matter composition. EF: enrichment factor (see text).

\begin{tabular}{lccrrc}
\hline & ${ }^{206} \mathrm{~Pb} /{ }^{207} \mathrm{~Pb}$ & $\pm 2 \mathrm{~s}$ & $\mathrm{Al}(\mathrm{mg} / \mathrm{kg})$ & $\mathrm{Pb}(\mathrm{mg} / \mathrm{kg})$ & $\mathrm{EF}$ \\
\hline $\mathrm{CSO}-1$ & $1.1568 \pm 0.0017$ & $461 \pm 23$ & $15442 \pm 2162$ & 53.8 \\
$\mathrm{CSO}-2$ & $1.1599 \pm 0.0031$ & $560 \pm 28$ & $13540 \pm 1896$ & 74.4 \\
$\mathrm{CSO}-3$ & $1.1531 \pm 0.0024$ & $801 \pm 40$ & $13641 \pm 1910$ & 105.7 \\
$\mathrm{CSO}-4$ & $1.1596 \pm 0.0017$ & $452 \pm 23$ & $12026 \pm 1684$ & 67.6 \\
$\mathrm{CSO}-5$ & $1.1559 \pm 0.0018$ & $515 \pm 26$ & $12517 \pm 1752$ & 74.1 \\
$\mathrm{CSO}-6$ & $1.1609 \pm 0.0040$ & $566 \pm 28$ & $9398 \pm 1316$ & 108.5 \\
$\mathrm{CSO}-7$ & $1.1571 \pm 0.0026$ & $478 \pm 24$ & $10881 \pm 1523$ & 79.0 \\
$\mathrm{CSO}-8$ & $1.1549 \pm 0.0026$ & $948 \pm 47$ & $15855 \pm 2220$ & 107.6 \\
$\mathrm{CSO}-9$ & $1.1557 \pm 0.0024$ & $588 \pm 29$ & $17547 \pm 2457$ & 60.3 \\
$\mathrm{CSO}-10$ & $1.1546 \pm 0.0015$ & $684 \pm 34$ & $17502 \pm 2450$ & 70.3 \\
$\mathrm{CSO}-11$ & $1.1545 \pm 0.0024$ & $656 \pm 33$ & $17056 \pm 2388$ & 69.2 \\
$\mathrm{CSO}-12$ & $1.1563 \pm 0.0024$ & $244 \pm 12$ & $4668 \pm 654$ & 94.0 \\
Median \pm SD & $1.1573 \pm 0.0025$ & $579 \pm 181$ & & & \\
\hline
\end{tabular}


Table 5. Orge River bulk and sieved bed sediments. EF: enrichment factor (see text).

\begin{tabular}{|c|c|c|c|c|c|c|c|c|}
\hline \multicolumn{3}{|c|}{${ }^{206} \mathrm{~Pb} /{ }^{207} \mathrm{~Pb} \pm 2 \mathrm{~s}$} & \multirow{2}{*}{$\begin{array}{c}\mathrm{Pb} \\
70.9\end{array}$} & \multirow{2}{*}{$\begin{array}{r}(\mathrm{mg} / \mathrm{kg}) \\
\pm 3.5\end{array}$} & \multirow{2}{*}{$\begin{array}{c}\text { Mass \% } \\
\text { bulk }\end{array}$} & \multicolumn{2}{|c|}{$\mathrm{Al}(\mathrm{mg} / \mathrm{kg})$} & \multirow{2}{*}{$\begin{array}{c}\mathrm{EF} \\
\mathrm{X}\end{array}$} \\
\hline D1S & 1.1497 & \pm 0.0016 & & & & $\mathrm{X}$ & & \\
\hline C1S & 1.1589 & 0.0031 & 44.2 & 2.2 & bulk & $\mathrm{X}$ & & $\mathrm{X}$ \\
\hline R1S & 1.1585 & 0.0025 & 32.8 & 1.6 & bulk & $\mathrm{X}$ & & $\mathrm{X}$ \\
\hline E1S & 1.1628 & 0.0020 & 64.5 & 3.2 & bulk & $\mathrm{X}$ & & $\mathrm{X}$ \\
\hline D3S & 1.1534 & 0.0043 & 46.3 & 2.3 & bulk & 20055 & \pm 2808 & 4.151 \\
\hline C3S & 1.1671 & 0.0043 & 10.3 & 0.5 & bulk & 8598 & 1204 & 2.156 \\
\hline R3S & 1.1687 & 0.0024 & 37.1 & 1.9 & bulk & 32736 & 4583 & 2.038 \\
\hline E3S & 1.1687 & 0.0033 & 64.5 & 3.2 & bulk & 39955 & 5594 & 2.906 \\
\hline L3S & 1.1569 & 0.0041 & 39.5 & 2.0 & bulk & 17535 & 2455 & 4.057 \\
\hline Y3S & 1.1589 & 0.0032 & 72.2 & 3.6 & bulk & 12405 & 1737 & 10.483 \\
\hline $\mathrm{D} 3 \mathrm{~S}>\mathbf{2 0 0}$ & 1.1586 & 0.0049 & 28.4 & 1.4 & 30.1 & 11913 & 1668 & 4.285 \\
\hline $\mathrm{C} 3 \mathrm{~S}>200$ & 1.1643 & 0.0032 & 11.3 & 0.6 & 39.7 & 8158 & 1142 & 2.493 \\
\hline$R 3 S>200$ & 1.1696 & 0.0045 & 38.5 & 1.9 & 23.9 & 34433 & 4821 & 2.013 \\
\hline$E 3 S>200$ & 1.1601 & 0.0025 & 69.1 & 3.5 & 41.5 & 44854 & 6279 & 2.773 \\
\hline $\mathrm{L} 3 S>200$ & 1.1518 & 0.0050 & 47.6 & 2.4 & 20.3 & 11819 & 1655 & 7.243 \\
\hline $\mathrm{Y} 3 S>200$ & 1.1492 & 0.0037 & 37.2 & 1.9 & 69.8 & 14431 & 2020 & 4.640 \\
\hline $63<\mathrm{D} 3 \mathrm{~S}<200$ & 1.1648 & 0.0034 & 35.3 & 1.8 & 50.7 & 23282 & 3259 & 2.726 \\
\hline $63<\mathrm{C} 3 \mathrm{~S}<200$ & 1.1542 & 0.0025 & 9.9 & 0.5 & 54.5 & 11060 & 1548 & 1.619 \\
\hline $63<\mathrm{R} 3 \mathrm{~S}<200$ & 1.1642 & 0.0050 & 31.5 & 1.6 & 34.9 & 27727 & 3882 & 2.045 \\
\hline $63<\mathrm{E} 3 \mathrm{~S}<200$ & 1.1670 & 0.0029 & 74.0 & 3.7 & 25.4 & 44198 & 6188 & 3.014 \\
\hline $63<L 3 S<200$ & 1.1591 & 0.0046 & 15.3 & 0.8 & 68.0 & 11367 & 1591 & 2.424 \\
\hline $63<\mathrm{Y} 3 \mathrm{~S}<200$ & 1.1536 & 0.0040 & 21.1 & 1.1 & 25.9 & 10768 & 1508 & 3.535 \\
\hline $\mathrm{D} 3 \mathrm{~S}<63$ & 1.1680 & 0.0044 & 50.7 & 2.5 & 19.1 & 41577 & 5821 & 2.196 \\
\hline $\mathrm{C} 3 \mathrm{~S}<63$ & 1.1668 & 0.0042 & 64.7 & 3.2 & 5.8 & 37132 & 5198 & 3.138 \\
\hline $\mathrm{R} 3 \mathrm{~S}<63$ & 1.1799 & 0.0040 & 37.9 & 1.9 & 41.3 & 43537 & 6095 & 1.569 \\
\hline$E 3 S<63$ & 1.1676 & 0.0044 & 50.8 & 2.5 & 33.1 & 40678 & 5695 & 2.248 \\
\hline$L 3 S<63$ & 1.1570 & 0.0049 & 73.6 & 3.7 & 11.7 & 45155 & 6322 & 2.936 \\
\hline$Y 3 S<63$ & 1.1550 & 0.0036 & 110.0 & 5.5 & 4.3 & 44335 & 6207 & 4.467 \\
\hline D4S & 1.1646 & 0.0023 & 40.5 & 2.0 & bulk & $\mathrm{X}$ & & $\mathrm{X}$ \\
\hline C4S & 1.1693 & 0.0018 & 14.6 & 0.7 & bulk & $\mathrm{X}$ & & $\mathrm{X}$ \\
\hline R4S & 1.1735 & 0.0011 & 15.8 & 0.8 & bulk & $\mathrm{X}$ & & $\mathrm{X}$ \\
\hline E4S & 1.1676 & 0.0018 & 64.7 & 3.2 & bulk & $\mathrm{X}$ & & $\mathrm{X}$ \\
\hline L4S & 1.1611 & 0.0018 & 26.8 & 1.3 & bulk & $\mathrm{X}$ & & $\mathrm{X}$ \\
\hline Y4S & 1.1513 & 0.0025 & 30.4 & 1.5 & bulk & $X$ & & $X$ \\
\hline RDS & 1.1443 & 0.0028 & 35.6 & 1.8 & bulk & $X$ & & $X$ \\
\hline
\end{tabular}

